ST A T E OF ILLINOIS

Dwight H. Green, Governor

DEPARTMENT OF REGISTRATION AND EDUCATION

Frank G. ThOMpson, Director

NATURAL HISTORY SURVEY DIVISION

Theodore H. Frison, Chief

\begin{tabular}{lll}
\hline Volume 22 & B U L L E T I N & Article 5 \\
\hline
\end{tabular}

\title{
Preferential Rating of Duck Food Plants
}

FRANK C. BELLROSE, JR. HARR Y G. A N DERSON

Printed by Authority of the State of Illinois

U R B A N A, I L L I N O I S

May 1943 


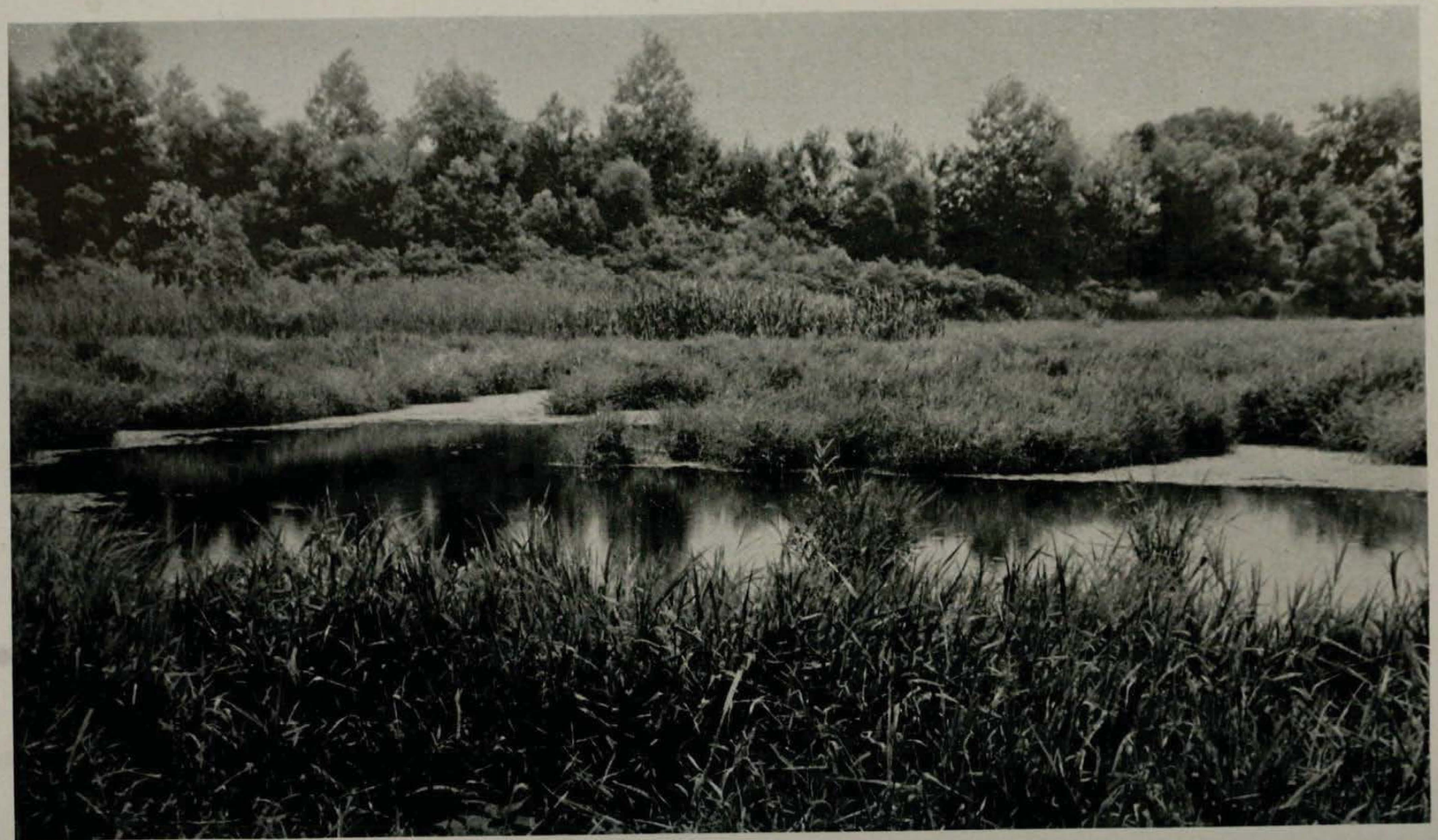

Kice cut-grass (Leersia oryzoides) growing in early fall along a tributary of the Illinois River. Research indicates that this moist-soil plant outranks all other uncultivated species as a source of food for migratory waterfowl in the Illinois River valley. 


\title{
Preferential Rating of
}

\section{Duck Food Plants}

\author{
FRANK C. BELLROSE, JR. \\ HARRY G. ANDERSON
}

D URING the past decade, the amount of research on the food plants used by migratory waterfowl has increased notably. The basis for much of this research has been data obtained by the U. S. Biological Survey (succeeded by the U. S. Fish and Wildlife Service) through analyses of the contents of several thousand duck stomachs, collection of which was begun in 1901. These data have recently been summarized by Martin \& Uhler (1939), who based their study on 7,998 stomachs, and by Cottam (1939).

Analyses of duck stomachs by the Biological Survey, other organizations and individuals has prompted wildlife investigators to attempt to ascertain the important duck food plants and their relative values in many regions of the United States. In all these studies, each plant species has been judged solely on its use, as determined by laboratory analyses of stomachs. While this method ascertains the important duck food plants, it does not reflect the relative values of these plants, for no consideration is given to the abundance of the plant species in the areas in which the stomachs have been collected. If in a certain area a plant species covering only 10 acres shows the same volume of seed use by ducks as another plant species covering 100 acres, the two plants should not be considered of equal value as duck food sources; indications are that the plant species occupying 10 acres is potentially 10 times as valuable as the species occupying 100 acres.

The shortcoming in the method of determining the value of various plants as food for waterfowl has been evident to several investigators. For instance, Martin \& Uhler (1939) in commenting on the percentage and ranking of duck food items in several tables state that "it will be desirable to have more extensive, careful field observations to supplement present conclusions, which are founded primarily on laboratory analyses." Concerning the heavy use made by ducks of pondweed and sedge seeds, Pirnie (1935) says that this may reflect abundance of the seeds rather than preference of ducks for these seeds. McAtee (1918) states that "superior availability after all is the guiding principle in the choice of food by birds."

The writers, ${ }^{*}$ 1938-1940, had the opportunity to make an intensive study of the occurrence and use of duck food plants in the Illinois River valley. A preliminary report covering the results of the 1938 investigation has been issued (Bellrose \& Anderson 1940). Because altered water levels in 1939 and 1940 greatly changed the food resources of many bottomland lakes through the development of extensive communities of moist-soil plants, it is thought desirable to summarize at this time the data for all 3 years.

\section{Method of Rating Food Plants}

In the present paper, the authors have attempted to obtain a numerical rating of the value of certain waterfowl plants by dividing the per cent of use made by ducks of the plant parts by the per cent of abundance of the plants. Per cent of use data are based on the volumetric

*Field work relating to plant species was done by Bellrose, then as now Assistant Game Technician of the Bellrose, then as How Aistory Survey. Analyses of stomach Illinois Natural History Aurvey. Analyses at the time employed contents was the work of Anderson, at the time employed by the Survey as Junior Biologist on Project 2-R of the Federal Aid in Wildlife Restoration Program, carried on in cooperation with the State Department of
vation and the U. S. Fish and Wildlife Service. 
measurement of the contents of 3,200 gizzards gathered at duck clubs during the 1938, 1939 and 1940 hunting seasons (Anderson ms.). Table 1 reveals the numbers of stomachs and the various species of ducks represented. The sample of dabbling duck gizzards is fairly proportionate to the occurrence of the

Table 1.-Duck stomachs examined in the present study.

\begin{tabular}{|c|c|c|c|c|}
\hline Duck & 1938 & 1939 & 1940 & TOTAL \\
\hline Mallard & 619 & 928 & 360 & 1,907 \\
\hline Pintail. & 222 & 408 & 39 & 669 \\
\hline Green-winged teal & 98 & 127 & - & 225 \\
\hline Blue-winged teal & 51 & 59 & - & 110 \\
\hline Baldpate......... & 33 & 49 & - & 82 \\
\hline Gadwall & 3 & 33 & 一 & 36 \\
\hline Shoveler. & 16 & 23 & - & 39 \\
\hline Canvasback. & 14 & 1 & - & 15 \\
\hline Ringneck ......... & 72 & 9 & 一 & 81 \\
\hline Lesser scaup ...... . & 2 & 1 & - & 3 \\
\hline Other ducks.... & 17 & 10 & 6 & 33 \\
\hline Total .... & 1,147 & 1,648 & 405 & 3,200 \\
\hline
\end{tabular}

different species of this type of duck in the Illinois River region. The sample of diving duck gizzards is not adequately representative of the occurrence of this waterfowl group in the region.

Considered in this paper are only uncultivated aquatic and moist-soil plants. Corn, usually an important duck food plant in the Illinois River valley, is not included in the calculations.

Per cent of abundance data are based upon the surface area in acres of the aquatic and moist-soil beds at the various lakes studied; this area in each case was obtained by plotting the vegetation by aspection and rough triangulation on large scale base maps and using a planimeter to measure the area covered by each species (Bellrose 1941). Table 2 gives the total area of aquatic and moistsoil vegetation for the lakes considered in this paper, and the number of gizzards examined from each area.

An index rating of 1.0 for a food plant indicates that this plant was used approximately in proportion to its abundance. The larger the figure, the greater is the value of the plant species as a duck food. Conversely, the smaller the figure, the lower is the value of the species.

We do not wish to pretend that the index figures listed here are the final and absolute evaluation of the food plants enumerated. Habits of waterfowl, plant differences, plant habitat characteristics, and inaccuracies in determining abundance of vegetation are factors tending to prevent minutely exact rating figures.

Ducks killed at any one lake may or may not have obtained their last meal there. Plant items in stomachs and banding data reveal that occasionally ducks have fed 10 or 100 or more miles from the place in which they are shot.

Food habits of various species of ducks differ widely, too, so that coontail may rank high at a certain place because of presence of many baldpates and gadwalls, or nutgrasses and pigweeds may rank high at another place because pintails and teals are abundant there.

In some instances changes in the ranking of a plant from year to year are due

Table 2.- Number of acres of duck food plants at various lakes in the Illinois River valley and the number of duck stomachs examined from each area.

\begin{tabular}{|c|c|c|c|c|c|c|}
\hline \multirow{2}{*}{ AREA } & \multicolumn{2}{|c|}{1938} & \multicolumn{2}{|c|}{1939} & \multicolumn{2}{|c|}{1940} \\
\hline & $\begin{array}{c}\text { Acres of } \\
\text { Vegetation }\end{array}$ & $\begin{array}{l}\text { Number of } \\
\text { Stomachs }\end{array}$ & $\begin{array}{c}\text { Acres of } \\
\text { Vegetation }\end{array}$ & $\begin{array}{l}\text { Number of } \\
\text { Stomachs }\end{array}$ & $\begin{array}{c}\text { Acres of } \\
\text { Vegetation }\end{array}$ & $\begin{array}{l}\text { Number of } \\
\text { Stomachs }\end{array}$ \\
\hline Duck Island . .......... & 1,255 & 207 & 1,539 & 162 & - & 一 \\
\hline Lakes.................. & 1,441 & 358 & 2,022 & 531 & 2,389 & 134 \\
\hline Crane Lake. . . . . . . . . & 425 & 293 & 466 & 342 & 531 & 142 \\
\hline Cuba Island. & 329 & 289 & 441 & 355 & 一 & - \\
\hline Douglas Lake. & - & - & 1,686 & 98 & - & 一 \\
\hline Goose Pond. & - & 一 & 908 & 160 & 968 & 129 \\
\hline Total ..... & 3,450 & 1,147 & 7,062 & 1,648 & 3,888 & 405 \\
\hline
\end{tabular}


to changes in seed production resulting from changes in environment. Such changes are well illustrated by water hemp at Clear Lake. In 1940, because of water level changes that reduced seed yield, water hemp had an index rating only half as great as in the previous year. Among aquatic plants, giant burreed, marsh smartweed and sago pondweed are notable as species that vary greatly in the yield of seed with variances in environmental conditions.

In some years, plant seeds present in abundance may be inaccessible to all or some ducks through the absence of water or through a depth of water too great for dabbling species. In other years, seeds of plants not present in those years may be available from previous years. For example, in 1938, be-

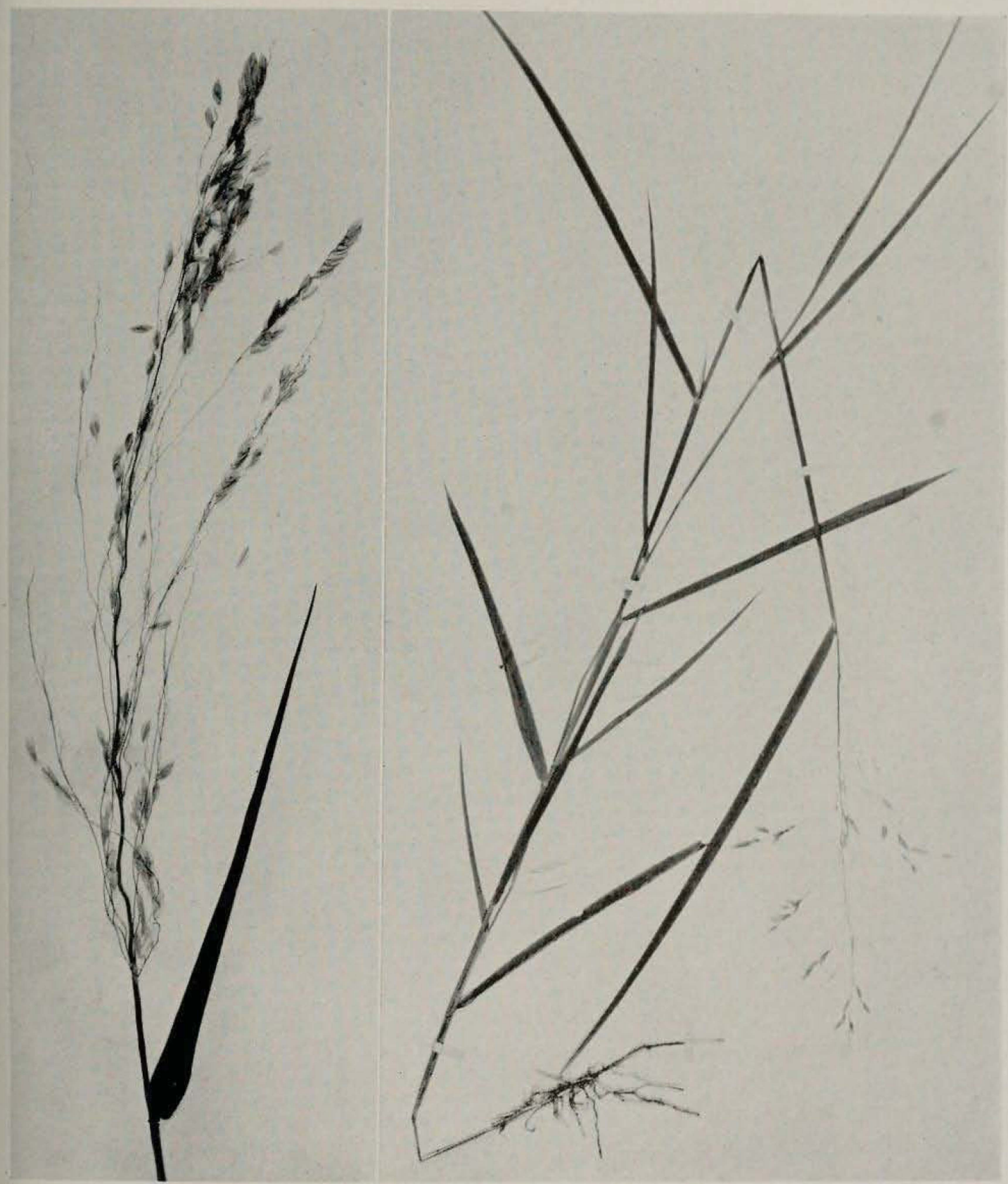

Fig. 1.-Rice cut-grass (Leersia oryzoides), or sawgrass, in most years and in most Illinois River valley habitats leads all other uncultivated plants in value as a source of food for ducks. Not only is this species valuable for its seed, which it produces in fair abundance, but its rootstocks and shoots also furnish food for waterfowl. 
cause of high water, moist-soil plantsmillets, smartweeds, nutgrasses and the like-were almost nonexistent in the Illinois River valley. Yet stomach analyses revealed that seed of these species formed almost one-fourth of the uncultivated foods taken. Noting that thousands of ducks were feeding on apparently barren mud flats and in shallow water, we conjectured that these waterfowl were consuming seeds deposited from plant beds occurring there in 1936 and 1937.

To ascertain the validity of this con-

Table 3.-Per cent of use, per cent of abundance, and index value of aquatic and moist-soil plants at certain lakes in the IIlinois River valley, 1938-40. Areas included are listed in table 2.

\begin{tabular}{|c|c|c|c|}
\hline Plant & $\begin{array}{c}\text { PER } \\
\text { CENT } \\
\text { OF } \\
\text { USE }\end{array}$ & $\begin{array}{c}\text { PER } \\
\text { CENT } \\
\text { OF } \\
\text { ABUN- } \\
\text { DANCE }\end{array}$ & $\begin{array}{l}\text { INDEX } \\
\text { VALUE }\end{array}$ \\
\hline Rice cut-grass.... & 25.53 & 1.93 & 13.32 \\
\hline Walter's millet... & 6.19 & 0.58 & 10.67 \\
\hline Nutgrasses........ & 10.85 & 1.53 & 7.12 \\
\hline $\begin{array}{l}\text { Largeseed, nodding } \\
\text { and other smart- } \\
\text { weeds* }{ }^{*} . \ldots \ldots \text {. }\end{array}$ & 4.44 & 1.09 & 4.07 \\
\hline $\begin{array}{l}\text { Japanese and wild } \\
\text { millets } \ldots . . . \ldots \ldots\end{array}$ & 11.76 & 3.45 & 3.41 \\
\hline Giant bur-reed . . . . & 0.26 & 0.10 & 2.60 \\
\hline Coontail ...... & 15.09 & 7.91 & 1.91 \\
\hline Duck potato..... & 2.73 & 2.79 & 0.98 \\
\hline Marsh smartweed. & 6.60 & 7.87 & 0.84 \\
\hline Buttonbush ....... & 2.62 & $1.13 \dagger$ & med. \\
\hline Longleaf pondweed. & 3.19 & 5.88 & 0.54 \\
\hline Spike rushes ....... & 0.16 & 0.34 & 0.47 \\
\hline Teal grass.......... & 1.99 & $0.02 \dagger$ & $?$ \\
\hline Water hen & 3.02 & 8.80 & 0.34 \\
\hline Marsh cord grass... & 0.05 & 0.21 & 0.24 \\
\hline White waterlily ..... & 0.08 & 0.74 & 0.10 \\
\hline Sago pondweed .... & 0.55 & 5.55 & 0.10 \\
\hline River bulrush.. & 0.50 & 26.02 & 0.02 \\
\hline American lotus.... & 0.35 & 23.26 & 0.02 \\
\hline Pickerelweed ...... & tr. & 0.01 & low \\
\hline Marsh mallow. & tr. & 0.01 & low \\
\hline Southern naiad. & tr. & 0.12 & low \\
\hline Wild rice...... & 0.00 & 0.59 & v. low \\
\hline Small pondweed. . & 0.00 & 0.05 & v. low \\
\hline $\begin{array}{l}\text { Longleaf } \\
\text { ammannia }\end{array}$ & & & \\
\hline Other plants & 3.72 & $* *$ & $\ldots$ \\
\hline
\end{tabular}

*Other than marsh smartweed. +Because of difficulty of measuring abundance of these plants, these figures are not accurate but represent minimum abundance. **No figure because of difficulty of measurement. $t r$. $t$ trace. $\mathrm{ab}$.=abundant. v. low=very low. med.=medium. jecture, in 1940 we collected from three places mud samples aggregating 18 square feet of surface. These samples yielded 2,500 seeds of Cyperus erythrorhizos, 2,000 seeds of $C$. strigosus and 550 seeds of water hemp, Acnida tuberculata. No plants had grown on these mud flats for 3 years. We believe that our findings substantiate the premise that large quantities of seeds deposited in one year may be available as food in succeeding years in which germination is precluded by unfavorable environmental conditions.

The areas of the various plant beds, as determined from the maps, are only approximate. In certain places there are seasonal changes in the plant communities, changes that result in error in calculating the abundance of the species

Table 4.- Per cent of use, per cent of abundance, and index value of aquatic and moist-soil plants at certain lakes in the Illinois River valley, 1938. Areas included are listed in table 2 .

\begin{tabular}{|c|c|c|c|}
\hline Plant & $\begin{array}{l}\text { Per } \\
\text { CENT } \\
\text { of } \\
\text { Use }\end{array}$ & $\begin{array}{c}\text { Per } \\
\text { Cent } \\
\text { of } \\
\text { ABun- } \\
\text { DANCE }\end{array}$ & $\begin{array}{l}\text { INDEX } \\
\text { VALUE }\end{array}$ \\
\hline Rice cut-grass .... & 28.46 & 0.73 & 39.00 \\
\hline Coontail .......... & 22.72 & 14.20 & 1.68 \\
\hline Nutgrasses... & 11.73 & tr. & high \\
\hline Marsh smartweed. & 9.61 & 14.43 & 0.66 \\
\hline Longleaf pondweed. & 5.85 & 13.48 & 0.43 \\
\hline Buttonbush ......... & 3.49 & ab. & low \\
\hline Teal grass .......... & 3.16 & tr. & med. \\
\hline Water hemp. & 2.17 & tr. & med. \\
\hline $\begin{array}{l}\text { Largeseed, nodding } \\
\text { and other smart- } \\
\text { weeds }{ }^{*} \ldots \ldots \ldots\end{array}$ & 1. 63 & tr. & med. \\
\hline Duck potato ....... & 1.40 & 7.14 & 0.20 \\
\hline Sago pondweed. & 0.89 & 8.81 & 0.10 \\
\hline American lotus ..... & 0.38 & 28.30 & 0.01 \\
\hline Giant bur-reed. & 0.35 & tr. & low \\
\hline River bulrush.... & 0.30 & 9.97 & 0.03 \\
\hline White waterlily & 0.21 & 0.80 & 0.26 \\
\hline Marsh cord grass & 0.15 & 0.70 & 0.21 \\
\hline Spike rushes ...... & 0.05 & 1.04 & 0.05 \\
\hline Pickerelweed .... & 0.00 & 0.40 & v. low \\
\hline Southern naiad. & 0.00 & tr. & v. low \\
\hline Mud plantain..... & 0.00 & tr. & v. low \\
\hline $\begin{array}{l}\text { Other plants (total } \\
\text { of } 50) \ldots \ldots \ldots \ldots\end{array}$ & 7.45 & $* *$ & \\
\hline
\end{tabular}

*Other than marsh smartweed. **No figure given because of difficulty of measurement. tr.=trace. ab.=abundant. med. = medium. v. low =very low. 
involved. A noticeable error occurred in the case of teal grass, Eragrostis hypnoides, because millets, pigweed and other plants growing over this species when the areas were surveyed made it virtually impossible to plot.

It may seem that the discrepancies enumerated above outweigh the benefits derived from this method of evaluation. However, we believe that, despite its limitations, the use-abundance rating gives a far more nearly accurate picture of the food value of a plant than do percentages based solely upon the amount of food taken.

Because of the different factors that may affect the availability of seeds or other plant parts of a particular species

Table 5.-Per cent of use, per cent of abundance, and index value of aquatic and moist-soil plants at certain lakes in the Illinois River valley, 1939. Areas included are listed in table 2 .

\begin{tabular}{|c|c|c|c|}
\hline Plant & $\begin{array}{l}\text { PER } \\
\text { CENT } \\
\text { OF } \\
\text { USE }\end{array}$ & $\begin{array}{c}\text { PeR } \\
\text { CENT } \\
\text { OF } \\
\text { ABUN- } \\
\text { DANCE }\end{array}$ & $\begin{array}{l}\text { INDEX } \\
\text { VALUE }\end{array}$ \\
\hline Walter's millet... & 9.37 & 0.26 & 36.04 \\
\hline Rice cut-grass.... & 22.25 & 1.47 & 15.13 \\
\hline $\begin{array}{l}\text { Nutgrasses ........ } \\
\text { Japanese and wild }\end{array}$ & 10.83 & 0.72 & 15.04 \\
\hline millets ............. & 14.82 & 5.44 & 2.72 \\
\hline Duck potato ..... & 3.94 & 1.48 & 2.66 \\
\hline $\begin{array}{l}\text { Largeseed, nodding } \\
\text { and other smart- } \\
\text { weeds }{ }^{*} \ldots \ldots \ldots\end{array}$ & 3.13 & tr. & high \\
\hline Spike rushes . . . . . . . & 0.25 & 0.10 & 2.50 \\
\hline Buttonbush. & 2.64 & $1.16 \dagger$ & med. \\
\hline Giant bur-reed. & 0.44 & 0.20 & 2.20 \\
\hline Coontail ........ & 13.62 & 6.28 & 2.19 \\
\hline Marsh smartweed ... & 7.75 & 6.73 & 1.15 \\
\hline Teal grass........ & 1.54 & tr. & med. \\
\hline Longleaf pondweed & 2.11 & 2.24 & 0.94 \\
\hline Water hemp....... & 1.65 & 2.22 & 0.74 \\
\hline Sago pondweed... & 0.38 & 6.14 & 0.06 \\
\hline American lotus. & 0.43 & 25.29 & 0.02 \\
\hline River bulrush.. & 0.65 & 37.47 & 0.02 \\
\hline Pickerelweed. & tr. & 0.03 & low \\
\hline Marsh mallow & tr. & 0.02 & low \\
\hline White waterlily. & tr. & 1. 15 & low \\
\hline Wild rice. & 0.00 & 1. 22 & low \\
\hline Marsh cord grass & 0.00 & 0.26 & low \\
\hline Southern naiad. . & 0.00 & 0.12 & low \\
\hline Other plants. & 4.20 & ** & $\ldots$ \\
\hline
\end{tabular}

*Other than marsh smartweed. **No figure given because of difficulty of measurement. tr. =trace. med.= medium. †Minimum figure. in any one year, it seems advisable to include yearly tables as well as a general summary table. Comparisons between years will aid in determining the influences of altered habitat conditions on the food value of plant species.

\section{Ratings of Food Plants Studied}

The value, as food for ducks, of the moist-soil and aquatic plants commonly occurring in the Illinois River valley is based on data presented in tables 3-6.

Rice cut-grass, Leersia oryzoides, fig. 1 , outranks all other species in food value for the 3 -year period, table 3 . In 1938 it ranked first by a wide margin, table 4. In 1939 it ranked second to Walter's millet, table 5; in 1940 it was slightly behind Japanese and wild millets combined, table 6 . This variance in

Table 6.- Per cent of use, per cent of abundance, and index value of aquatic and moist-soil plants at certain lakes in the Illinois River valley, 1940. Areas included are listed in table 2 .

\begin{tabular}{|c|c|c|c|}
\hline Plant & $\begin{array}{l}\text { PER } \\
\text { CENT } \\
\text { OF } \\
\text { USE }\end{array}$ & $\begin{array}{c}\text { PER } \\
\text { CENT } \\
\text { OF } \\
\text { ABUN- } \\
\text { DANCE }\end{array}$ & $\begin{array}{l}\text { INDEX } \\
\text { VALUE }\end{array}$ \\
\hline $\begin{array}{l}\text { Japanese and wild } \\
\text { millets............ }\end{array}$ & 21.26 & 2.92 & 7.28 \\
\hline Rice cut-grass..... & 28.72 & 4.15 & 6.92 \\
\hline Walter's millet. & 7.64 & 1.63 & 4.68 \\
\hline $\begin{array}{l}\text { Largeseed, nodding } \\
\text { and other smart- } \\
\text { weeds* ........ }\end{array}$ & 9.56 & 3.94 & 2.43 \\
\hline Nutgrasses ........ & 8.63 & 4.18 & 2.06 \\
\hline Duck potato.... & 1.37 & 1.41 & 0.97 \\
\hline Coontail ......... & 3.60 & 5.16 & 0.70 \\
\hline Spike rushes.. & 0.08 & 0.13 & 0.60 \\
\hline Buttonbush. & 0.71 & 2.05 & 0.35 \\
\hline Teal grass.......... & 0.97 & $0.08 \dagger$ & ? \\
\hline Water hemp.... & 8.53 & 28.03 & 0.30 \\
\hline Longleaf pondweed & 1.38 & 5.58 & 0.25 \\
\hline Sago pondweed ... & 0.38 & 1.58 & 0.24 \\
\hline Marsh smartweed. & 0.73 & 4.06 & 0.18 \\
\hline River bulrush ...... & 0.39 & 20.34 & 0.02 \\
\hline American lotus.... & 0.05 & 14.27 & 0.004 \\
\hline Southern naiad... & 0.00 & 0.22 & low \\
\hline Small pondweed. & 0.00 & 0.20 & low \\
\hline $\begin{array}{l}\text { Longleaf } \\
\text { ammannia... }\end{array}$ & 0.00 & 0.07 & low \\
\hline Others, many & 6.00 & $* *$ & \\
\hline
\end{tabular}

*Other than marsh smartweed. **No figure given because of difficulty of measurement. †Minimum figure. 
cause of high water, moist-soil plantsmillets, smartweeds, nutgrasses and the like-were almost nonexistent in the Illinois River valley. Yet stomach analyses revealed that seed of these species formed almost one-fourth of the uncultivated foods taken. Noting that thousands of ducks were feeding on apparently barren mud flats and in shallow water, we conjectured that these waterfowl were consuming seeds deposited from plant beds occurring there in 1936 and 1937.

To ascertain the validity of this con-

Table 3.-Per cent of use, per cent of abundance, and index value of aquatic and moist-soil plants at certain lakes in the Illinois River valley, 1938-40. Areas included are listed in table 2.

\begin{tabular}{|c|c|c|c|}
\hline Plant & $\begin{array}{l}\text { PER } \\
\text { CENT } \\
\text { OF } \\
\text { UsE }\end{array}$ & $\begin{array}{c}\text { Per } \\
\text { Cent } \\
\text { of } \\
\text { ABun- } \\
\text { DANCE }\end{array}$ & $\begin{array}{l}\text { INDEX } \\
\text { VALUE }\end{array}$ \\
\hline Rice cut-grass... & 25.53 & 1.93 & 13.32 \\
\hline Walter's millet. & 6.19 & 0.58 & 10.67 \\
\hline Nutgrasses........ & 10.85 & 1.53 & 7.12 \\
\hline $\begin{array}{l}\text { Largeseed, nodding } \\
\text { and other smart- } \\
\text { weeds* ......... }\end{array}$ & 4.44 & 1.09 & 4.07 \\
\hline $\begin{array}{l}\text { Japanese and wild } \\
\text { millets } \ldots \ldots \ldots\end{array}$ & 11.76 & 3.45 & 3.41 \\
\hline Giant bur-reed ..... & 0.26 & 0.10 & 2.60 \\
\hline Coontail ............ & 15.09 & 7.91 & 1.91 \\
\hline Duck potato ........ & 2.73 & 2.79 & 0.98 \\
\hline Marsh smartweed. . & 6.60 & 7.87 & 0.84 \\
\hline Buttonbush...... & 2.62 & $1.13 \dagger$ & med. \\
\hline Longleaf pondweed. & 3.19 & 5.88 & 0.54 \\
\hline Spike rushes . ...... & 0.16 & 0.34 & 0.47 \\
\hline Teal grass.......... & 1.99 & $0.02 \dagger$ & ? \\
\hline Water hemp ....... & 3.02 & 8.80 & 0.34 \\
\hline Marsh cord grass... & 0.05 & 0.21 & 0.24 \\
\hline White waterlily .... & 0.08 & 0.74 & 0.10 \\
\hline Sago pondweed .... & 0.55 & 5.55 & 0.10 \\
\hline River bulrush ....... & 0.50 & 26.02 & 0.02 \\
\hline American lotus ..... & 0.35 & 23.26 & 0.02 \\
\hline Pickerelweed ....... & tr. & 0.01 & low \\
\hline Marsh mallow ..... & tr. & 0.01 & low \\
\hline Southern naiad.... & tr. & 0.12 & low \\
\hline Wild rice .......... & 0.00 & 0.59 & v. low \\
\hline Small pondweed. . & 0.00 & 0.05 & v. low \\
\hline $\begin{array}{l}\text { Longleaf } \\
\text { ammannia .... }\end{array}$ & 0.00 & 0.02 & v. low \\
\hline Other plants. & 3.72 & $* *$ & $\ldots$ \\
\hline
\end{tabular}

*Other than marsh smartweed. †Because of difficulty of measuring abundance of these plants, these figures are not accurate but represent minimum abundance. ${ }^{* *}$ No figure because of difficulty of measurement. $t r .=t r a c e$. $\mathrm{ab} .=$ abundant. $\mathrm{v}$. low=very low. med.=medium. jecture, in 1940 we collected from three places mud samples aggregating 18 square feet of surface. These samples yielded 2,500 seeds of Cyperus erythrorhi$z o s, 2,000$ seeds of $C$. strigosus and 550 seeds of water hemp, Acnida tuberculata. No plants had grown on these mud flats for 3 years. We believe that our findings substantiate the premise that large quantities of seeds deposited in one year may be available as food in succeeding years in which germination is precluded by unfavorable environmental conditions.

The areas of the various plant beds, as determined from the maps, are only approximate. In certain places there are seasonal changes in the plant communities, changes that result in error in calculating the abundance of the species

Table 4.-Per cent of use, per cent of abundance, and index value of aquatic and moist-soil plants at certain lakes in the Illinois River valley, 1938. Areas included are listed in table 2 .

\begin{tabular}{|c|c|c|c|}
\hline Plant & $\begin{array}{c}\text { PER } \\
\text { CENT } \\
\text { OF } \\
\text { USE }\end{array}$ & $\begin{array}{c}\text { Per } \\
\text { CENT } \\
\text { OF } \\
\text { ABUN- } \\
\text { DANCE }\end{array}$ & $\begin{array}{l}\text { INDEX } \\
\text { VALUE }\end{array}$ \\
\hline Rice cut-grass... & 28.46 & 0.73 & 39.00 \\
\hline Coontail ........... & 22.72 & 14.20 & 1.68 \\
\hline Nutgrasses.... & 11.73 & tr. & high \\
\hline Marsh smartweed. & 9.61 & 14.43 & 0.66 \\
\hline Longleaf pondweed. & 5.85 & 13.48 & 0.43 \\
\hline Buttonbush ........ & 3.49 & ab. & low \\
\hline Teal grass......... & 3.16 & tr. & med. \\
\hline Water hemp.. & 2.17 & tr. & med. \\
\hline $\begin{array}{l}\text { Largeseed, nodding } \\
\text { and other smart- } \\
\text { weeds }{ }^{*} \ldots \ldots \ldots\end{array}$ & 1.63 & tr. & med. \\
\hline Duck potato....... & 1.40 & 7.14 & 0.20 \\
\hline Sago pondweed. & 0.89 & 8.81 & 0.10 \\
\hline American lotus. & 0.38 & 28.30 & 0.01 \\
\hline Giant bur-reed .... & 0.35 & tr. & low \\
\hline River bulrush. . & 0.30 & 9.97 & 0.03 \\
\hline White waterlily. & 0.21 & 0.80 & 0.26 \\
\hline Marsh cord grass... & 0.15 & 0.70 & 0.21 \\
\hline Spike rushes ....... & 0.05 & 1.04 & 0.05 \\
\hline Pickerelweed ...... & 0.00 & 0.40 & v. low \\
\hline Southern naiad. & 0.00 & tr. & v. low \\
\hline Mud plantain ..... & 0.00 & tr. & v. low \\
\hline $\begin{array}{l}\text { Other plants (total } \\
\text { of } 50) \ldots \ldots \ldots \ldots\end{array}$ & 7.45 & $* *$ & $\ldots$ \\
\hline
\end{tabular}

*Other than marsh smartweed. **No figure given because of difficulty of measurement. tr. =trace. ab.=abundant. med. = medium. v. low $=$ very low. 
involved. A noticeable error occurred in the case of teal grass, Eragrostis hypnoides, because millets, pigweed and other plants growing over this species when the areas were surveyed made it virtually impossible to plot.

It may seem that the discrepancies enumerated above outweigh the benefits derived from this method of evaluation. However, we believe that, despite its limitations, the use-abundance rating gives a far more nearly accurate picture of the food value of a plant than do percentages based solely upon the amount of food taken.

Because of the different factors that may affect the availability of seeds or other plant parts of a particular species

Table 5.-Per cent of use, per cent of abundance, and index value of aquatic and moist-soil plants at certain lakes in the Illinois River valley, 1939. Areas included are listed in table 2 .

\begin{tabular}{|c|c|c|c|}
\hline Plant & $\begin{array}{c}\text { PER } \\
\text { CENT } \\
\text { of } \\
\text { Use }\end{array}$ & $\begin{array}{c}\text { Per } \\
\text { CENT } \\
\text { of } \\
\text { ABUn- } \\
\text { DANCE }\end{array}$ & $\begin{array}{l}\text { INDEX } \\
\text { VALUE }\end{array}$ \\
\hline Walter's millet. & 9.37 & 0.26 & 36.04 \\
\hline Rice cut-grass. & 22.25 & 1. 47 & 15.13 \\
\hline $\begin{array}{l}\text { Nutgrasses ......... } \\
\text { Japanese and wild }\end{array}$ & 10.83 & 0.72 & 15.04 \\
\hline $\begin{array}{l}\text { Japanese and wild } \\
\text { millets ............. }\end{array}$ & 14.82 & 5.44 & 2.72 \\
\hline Duck potato ...... & 3.94 & 1.48 & 2.66 \\
\hline $\begin{array}{l}\text { Largeseed, nodding } \\
\text { and other smart- } \\
\text { weeds* ......... }\end{array}$ & 3.13 & tr. & high \\
\hline Spike rushes ....... & 0.25 & 0.10 & 2.50 \\
\hline Buttonbush. . & 2.64 & $1.16^{\dagger}$ & med. \\
\hline Giant bur-reed & 0.44 & 0.20 & 2.20 \\
\hline Coontail ...... & 13.62 & 6.28 & 2.19 \\
\hline Marsh smartweed. & 7.75 & 6.73 & 1. 15 \\
\hline Teal grass ........ & 1. 54 & tr. & med. \\
\hline Longleaf pondweed & 2.11 & 2.24 & 0.94 \\
\hline Water hemp ....... & 1.65 & 2.22 & 0.74 \\
\hline Sago pondweed & 0.38 & 6.14 & 0.06 \\
\hline American lotus. & 0.43 & 25.29 & 0.02 \\
\hline River bulrush. & 0.65 & 37.47 & 0.02 \\
\hline Pickerelweed. & tr. & 0.03 & low \\
\hline Marsh mallow & tr. & 0.02 & low \\
\hline White waterlily & tr. & 1. 15 & low \\
\hline Wild rice..... & 0.00 & 1. 22 & low \\
\hline Marsh cord grass & 0.00 & 0.26 & low \\
\hline Southern naiad. & 0.00 & 0.12 & low \\
\hline Other plants. . & 4.20 & $* *$ & $\ldots$ \\
\hline
\end{tabular}

*Other than marsh smartweed. **No figure given because of difficulty of measurement. $\mathrm{tr}$.=trace. med.= medium. †Minimum figure. in any one year, it seems advisable to include yearly tables as well as a general summary table. Comparisons between years will aid in determining the influences of altered habitat conditions on the food value of plant species.

\section{Ratings of Food Plants Studied}

The value, as food for ducks, of the moist-soil and aquatic plants commonly occurring in the Illinois River valley is based on data presented in tables 3-6.

Rice cut-grass, Leersia oryzoides, fig. 1 , outranks all other species in food value for the 3 -year period, table 3 . In 1938 it ranked first by a wide margin, table 4. In 1939 it ranked second to Walter's millet, table 5; in 1940 it was slightly behind Japanese and wild millets combined, table 6 . This variance in

Table 6.-Per cent of use, per cent of abundance, and index value of aquatic and moist-soil plants at certain lakes in the Illinois River valley, 1940. Areas included are listed in table 2 .

\begin{tabular}{|c|c|c|c|}
\hline Plant & $\begin{array}{c}\text { Per } \\
\text { CENT } \\
\text { OF } \\
\text { Use }\end{array}$ & $\begin{array}{c}\text { Per } \\
\text { CENT } \\
\text { OF } \\
\text { ABUn- } \\
\text { DANCE }\end{array}$ & $\begin{array}{l}\text { INDEX } \\
\text { VALUE }\end{array}$ \\
\hline $\begin{array}{l}\text { Japanese and wild } \\
\text { millets } \ldots \ldots \ldots\end{array}$ & 21.26 & 2.92 & 7.28 \\
\hline Rice cut-grass... & 28.72 & 4.15 & 6.92 \\
\hline Walter's millet. & 7.64 & 1.63 & 4.68 \\
\hline $\begin{array}{l}\text { Largeseed, nodding } \\
\text { and other smart- } \\
\text { weeds* ......... }\end{array}$ & 9.56 & 3.94 & 2.43 \\
\hline Nutgrasses........ & 8.63 & 4. 18 & 2.06 \\
\hline Duck potato. & 1.37 & 1.41 & 0.97 \\
\hline Coontail. & 3.60 & 5.16 & 0.70 \\
\hline Spike rushes... & 0.08 & 0.13 & 0.60 \\
\hline Buttonbush ..... & 0.71 & 2.05 & 0.35 \\
\hline Teal grass... & 0.97 & $0.08 \dagger$ & ? \\
\hline Water hemp. & 8.53 & 28.03 & 0.30 \\
\hline Longleaf pondweed & 1. 38 & 5.58 & 0.25 \\
\hline Sago pondweed .... & 0.38 & 1. 58 & 0.24 \\
\hline Marsh smartweed. & 0.73 & 4.06 & 0.18 \\
\hline River bulrush.... & 0.39 & 20.34 & 0.02 \\
\hline American lotus. & 0.05 & 14.27 & 0.004 \\
\hline Southern naiad. & 0.00 & 0.22 & low \\
\hline Small pondweed & 0.00 & 0.20 & low \\
\hline $\begin{array}{l}\text { Longleaf } \\
\text { ammannia. }\end{array}$ & 0.00 & 0.07 & low \\
\hline Others, many . & 6.00 & & $\ldots$. \\
\hline
\end{tabular}

*Other than marsh smartweed. **No figure given because of difficulty of measurement. †Minimum figure. 
value is brought about largely by local habitat changes. From studies made of seed production in 1941 by Low \& Bellrose (ms.) it is apparent that dry soil greatly lowers the seed productivity of rice cut-grass; furthermore, unless there is an inch or two of water over the rootstocks during the fall, those items, which also are a waterfowl food, are not available to ducks. At several lakes where index values of rice cut-grass were obtained throughout the 3-year period, this plant ranked first at five and second

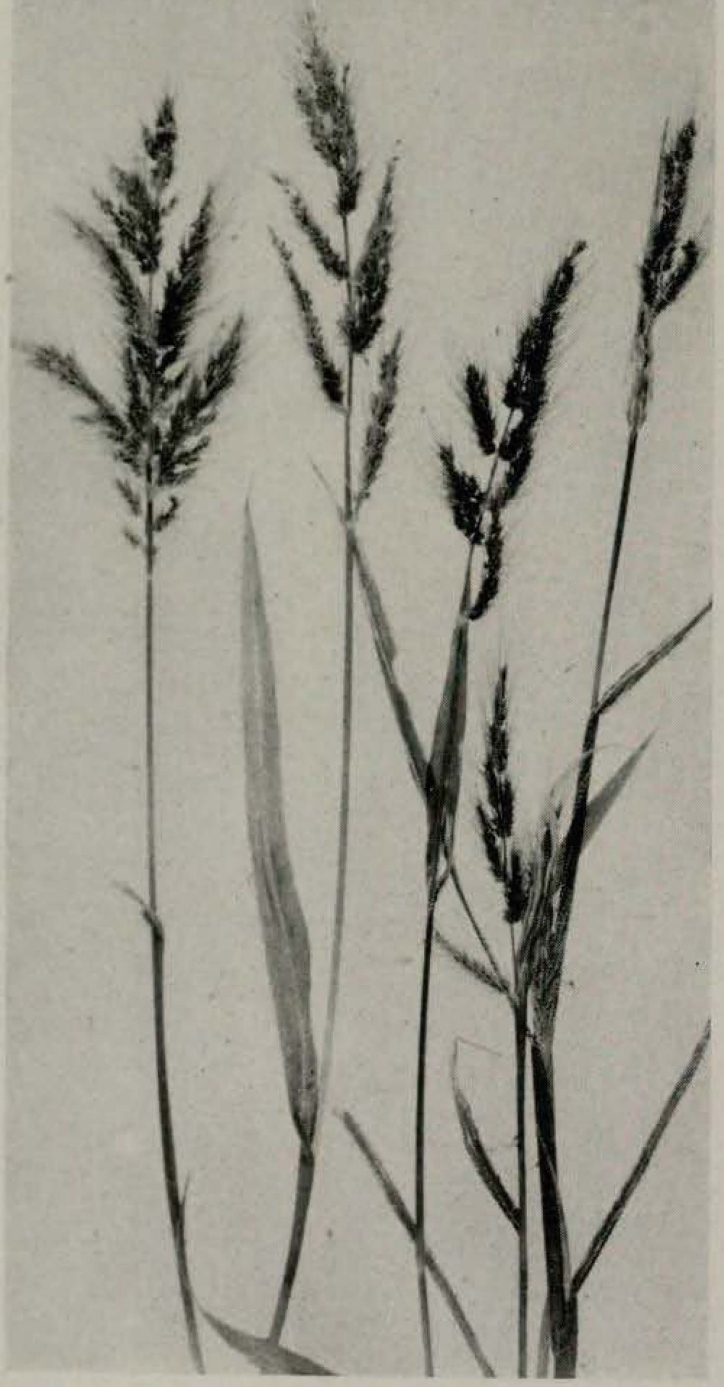

Fig. 2.-Walter's millet (Echinochloa Walteri) outranks Japanese millet in certain habitats as a food for migratory waterfowl in the Illinois River region. While its favorable position may be due in most instances to greater seed production, it may be due at times to a diet preference on the part of pintails and teals. at four areas. A check of the environmental conditions of these nine areas revealed that the first five were more

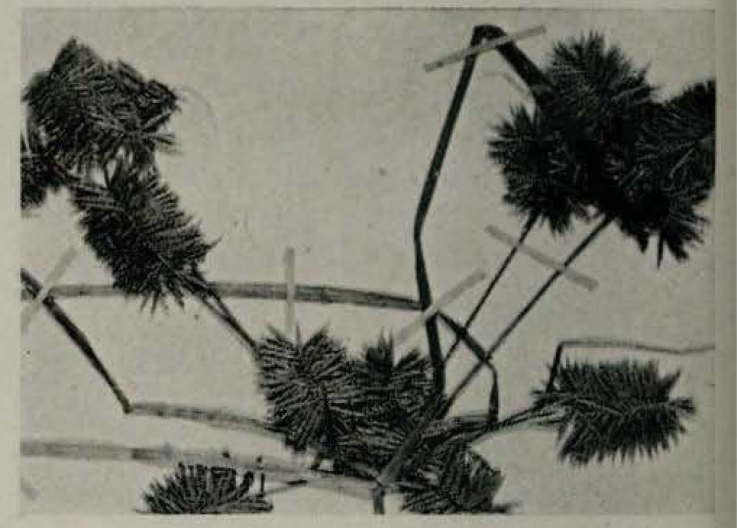

Fig. 3.-Nutgrasses (Cyperus spp.), as a group ranking fifth in value among Illinois River valley duck food plants, produce large quantities of minute seeds. Straw-colored cyperus ( $C$. strigosus) is pictured here.

favorable habitats for the plant than were the others.

Walter's millet, Echinochloa Walteri, fig. 2, approaches rice cut-grass in value, according to the index figures in table 3. It is to be expected that, like many other plants, this species varies in value with the year and habitat, its value depending on its own seed production and the availability of other foods. Although Martin \& Uhler (1939) regard the smaller seeds of this species less important as a duck food than those of wild millet, E. crusgalli, we believe that Walter's millet may locally, in certain years, be the more valuable species. For example, at Clear Lake in 1940, Walter's millet was slightly less abundant than wild and Japanese millets combined. However, Walter's millet amounted to 16.52 per cent of the native food plant items taken from the stomachs of ducks shot at this lake, while wild and Japanese millets totaled only 9.24 per cent.

We believe that the greater value of Walter's millet may lie in a generally heavier seed yield of this plant or in the fact that pintails and teals prefer the small seeds of this species to the larger ones of the other millets. We know that pintail and teal diets are made up of smaller seeds than are those of mallards, baldpates, gadwalls and the like, and that the number of pintail and teal 
stomachs analyzed from Clear Lake was proportionally larger than at lakes at which Walter's millet did not rank so high. Low \& Bellrose (ms.) found that, in 1941, wild and Japanese millets produced considerably greater quantities of seed per unit of area than did Walter's

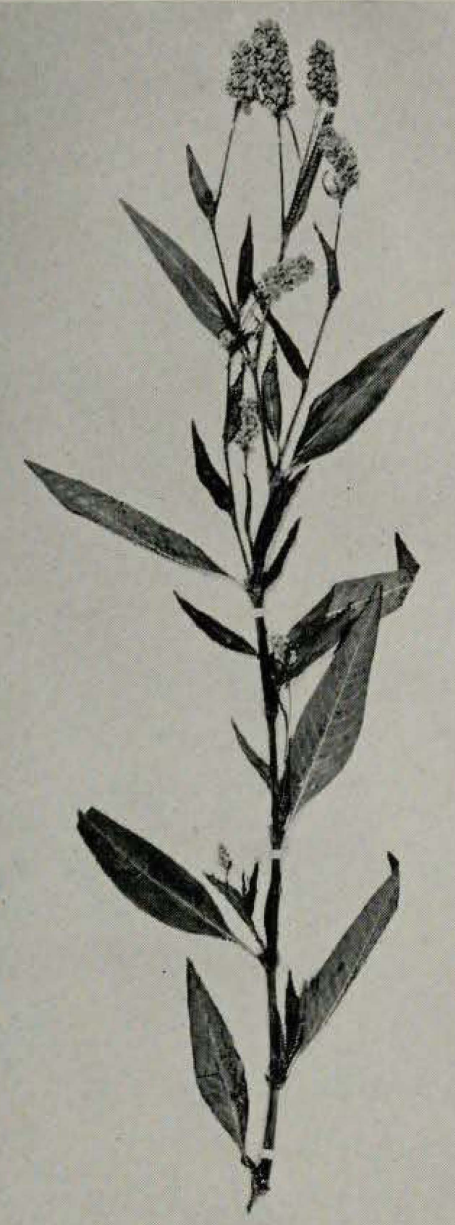

Fig. 4.-Largeseed smartweed (Polygonum pennsylvanicum), in contrast to nodding smartweed, has thick, erect spikes. This and other moist-soil smartweeds constitute a group that appears to be slightly more valuable than the nutgrasses, but less valuable than the millets, as a source of food for migratory waterfowl.

millet. However, in that year, high water so retarded growth of Walter's millet that plants were only 2 to 5 feet high, whereas in 1939 and 1940 they were 7 to 9 feet high. The taller plants had considerably larger inflorescences and therefore produced much more seed.

Nutgrasses, fig. 3 , are in third position in table 3 . Although the index rating derived from data obtained in all 3 years places this group, Cyperus erythrorhizos, C. strigosus and C. esculentus, third in value, we believe that an inaccuracy in figures resulted from the fact that waterfowl fed on seeds deposited prior to 1938 on mud flats that were bare in that year and that were therefore recorded as supporting no nutgrass plants. All evidence points to the fact that a somewhat similar situation occured in 1939, when water prevented plants from appearing on many areas. In 1940, water levels were low earlier than in the 2 preceding years, so that by fall all mud flats were covered by a rank growth of vegetation. We believe that

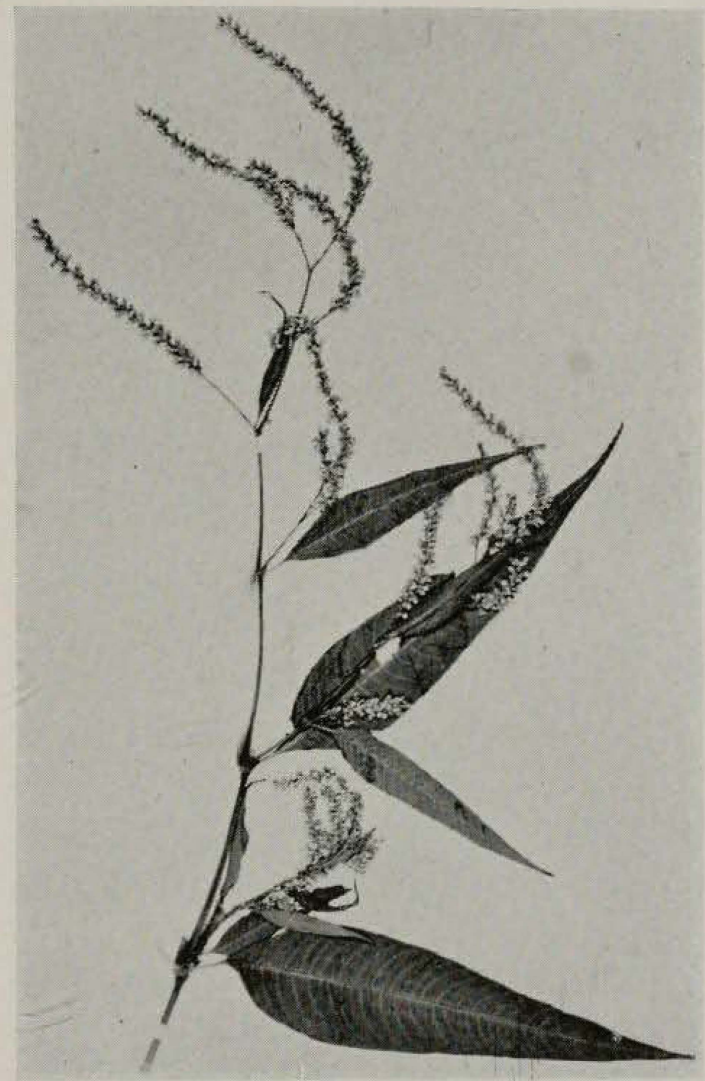

Fig. 5.-Nodding smartweed (Polygonum lapathifolium) grows on mud flats and other moist places. Its long, drooping, densely flowered spikes distinguish it from other smartweeds.

the index value as given in 1940 for this species is the most nearly accurate, table 6 . This rating placed the nutgrasses above duck potato in value - the numerical value was over twice as great, 
in fact-but below the group consisting principally of nodding, large-seed and swamp smartweed.

The relative value of the three species of nutgrasses may be judged by the following facts: Cyperus erythrorhizos, represented by 56.5 per cent of the total nutgrass seed found in duck gizzards, was much more abundant than $C$. strigosus, represented by 19.0 per cent of the nutgrass seed; $C$. esculentus, however, made up 24.5 per cent of the total nutgrass seed, even though less abundant than C. strigosus. This would indicate that $C$. esculentus was slightly better than $C$. erythrorhizos, which, in turn, was better than $C$. strigosus.

Moist-soil smartweeds, consisting of largeseed smartweed, Polygonum pennsylvanicum, fig. 4, nodding smartweed, $P$. lapathifolium, fig. 5, swamp smartweed, $P$. hydropiperoides, and minor quantities of other species, rank fourth for the 3-year period, table 3 . However, here also the same factors prevail that were responsible for an error in the index value of the nutgrasses: in many places seeds deposited

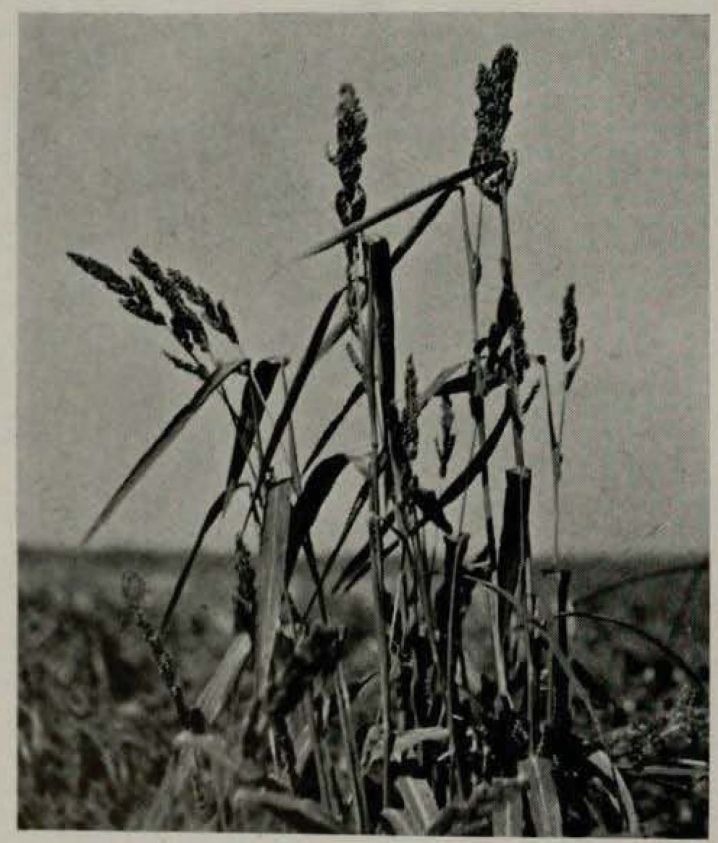

Fig. 6.- Japanese millet (Echinochloa frumentacea) under favorable growing conditions is one of the greatest seed producers among the duck food plants of the Illinois River valley. Because its seed production is greatly dependent on growing conditions, its comparative value ranges from excellent to fair in the course of several years. in one year were consumed the next, when germination did not occur and plants were not recorded. The 1940 index rating of 2.43 in table 6 is probably the most nearly accurate. It places these species slightly above the nutgrasses in value.

Wild and Japanese millets, Echinochloa crusgalli and E. frumentacea, fig. 6 , appear fifth in order of preference in table 3, covering 1938, 1939 and 1940. For some reason, waterfowl did not ob-

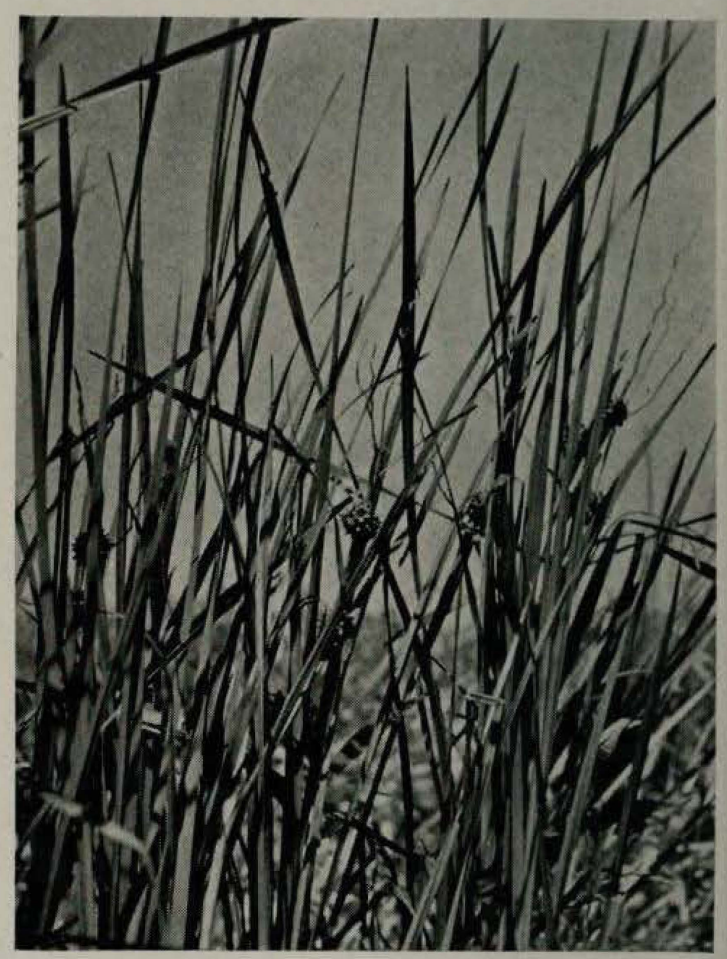

Fig. 7.-Giant bur-reed (Sparganium eurycarpum) ranks sixth as a duck food plant in the Illinois River region. Its value here is considerably higher than it is generally accorded elsewhere. The globose heads are composed of nutlike, beaked seeds that are eaten by ducks.

tain appreciable amounts of seed of these species from mud flats in 1938. Had they done so, the status of these millets would undoubtedly have been raised above that of the smartweeds. Table 6 shows that Japanese and wild millets headed the list in 1940, when they were slightly better than rice cutgrass.

As in other species, millets vary in seed yield with habitat conditions. Furthermore, time of planting greatly affects seed production. Japanese millet sown in the Illinois River valley after 


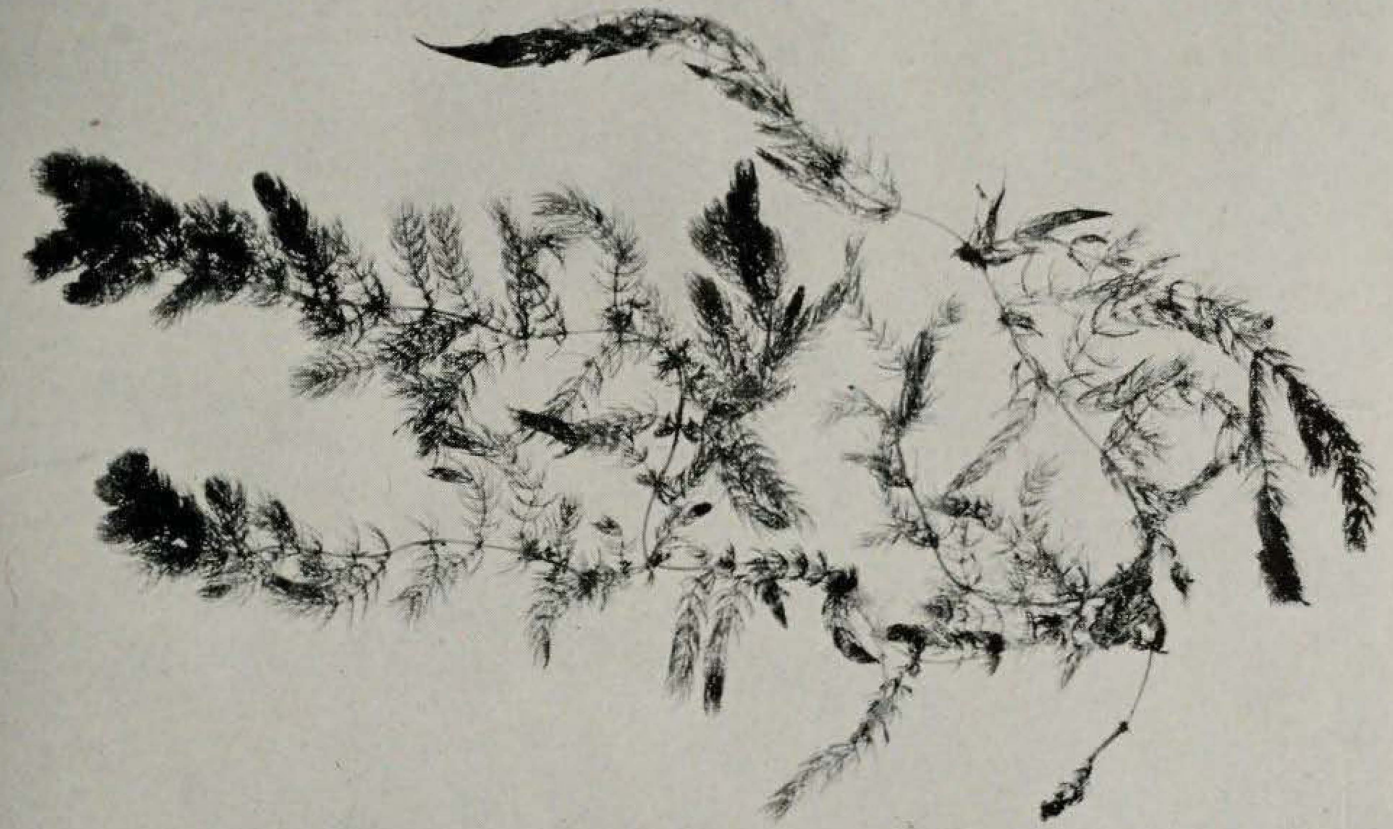

Fig. 8.-Coontail (Ceratophyllum demersum) ranks below the moist-soil plants in value as a source of food for waterfowl, but leads the truly aquatic species. Ducks feed mainly on its leaves and stems.

Aug. 1 often fails to ripen before frost. On the other hand, this millet sown in June may mature, the seed shatter and germinate the same summer. In the Illinois River valley this second growth of millet has never matured before frost. We do not know just how operative the above conditions were in lowering the value of this species in 1939 , but we know that the water receded in many lake basins 2 weeks earlier in 1940 than in 1939 to give the millet a longer growing season.

Giant bur-reed, Sparganium eurycarpum, fig. 7 , with an index value in table 3 of 2.60, ranks as a much better duck food plant in the Illinois River valley than it is generally believed to be. Studies by Low \& Bellrose (ms.) in 1941 on the seed yield of this species reveal that it produced about three times as much seed in areas with stable water levels as in areas with semistable water levels. In the various types of areas combined, giant bur-reed in 1941 produced more seed per unit of area than either largeseed or nodding smartweed.
Coontail, Ceratophyllum demersum, fig. 8 , ranking slightly below giant burreed in value, table 3 , is an excellent

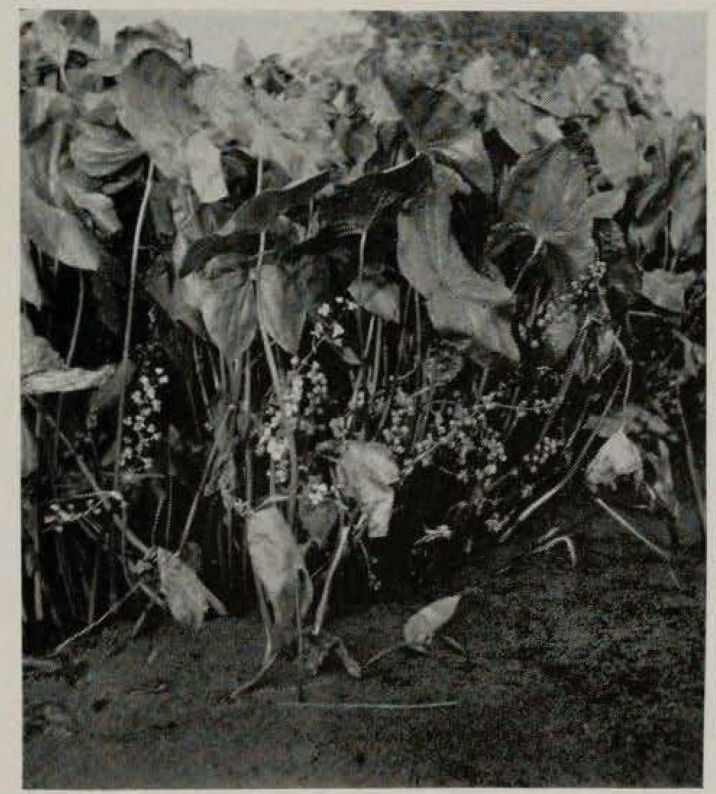

Fig. 9.-Duck potato (Sagittaria latifolia) is valued by ducks more for its seed than for its large, deeply buried tubers. 
food for baldpates and gadwalls. It furnishes little seed, but ducks make extensive use of the leaves and stems.

Teal grass, Eragrostis hypnoides, has a status that cannot be judged by any index figures derived from use and abundance data recorded for this species, tables $3,4,5$ and 6 . This is evident from the fact that in 1938 and 1939 it formed respectively 3.16 and 1.54 per cent of the food taken, while only a few small patches of plants were seen on ex- tensive mud flats around several lakes. In all probability, ducks in those years obtained seeds deposited by growths of previous seasons. This small, procumbent plant in 1940 was overgrown by pigweeds, millets and smartweeds to such an extent that accurate mapping of the areas covered by the numerous scattered patches was impossible.

From its relatively high use and apparently low occurrence, we believe that teal grass ranks above duck potato in

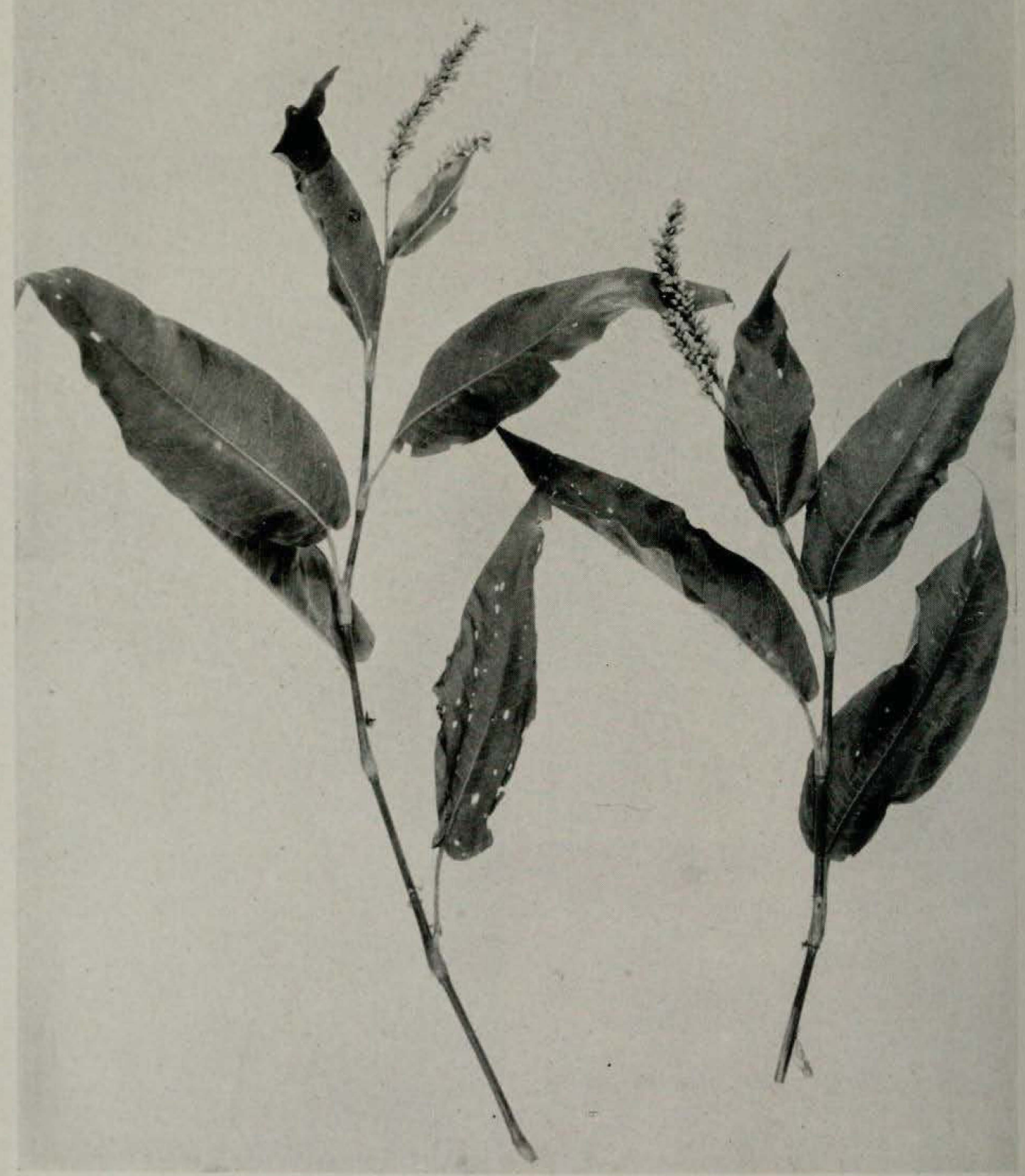

Fig. 10.-Marsh smartweed (Polygonum Muhlenbergii), one of the few smartweeds that grows in water, can readily be identified by its bright pink blossoms. It is not so valuable a duck food plant as largeseed or nodding smartweeds because it does not produce so much seed. 


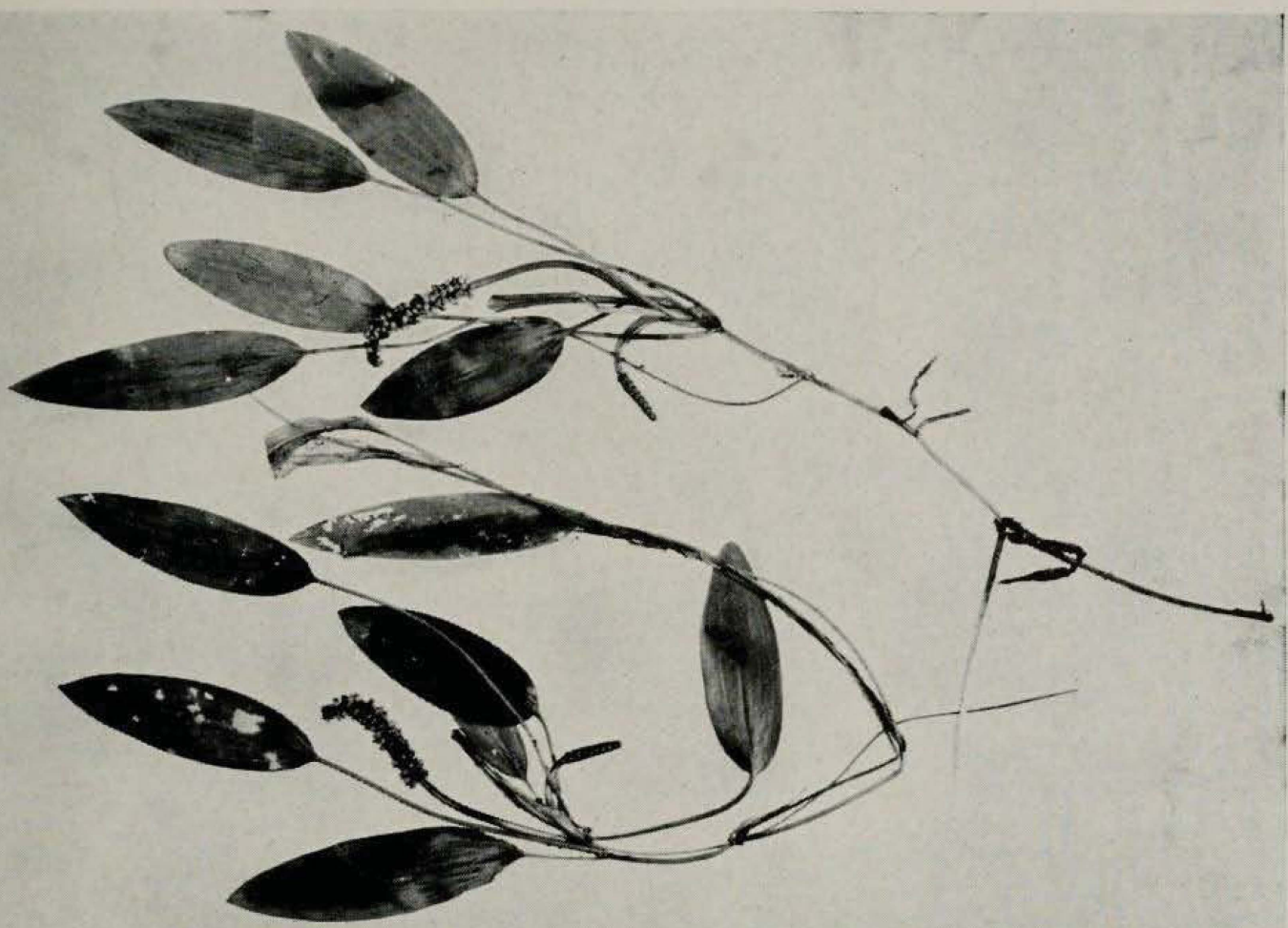

Fig. 11. - Longleaf pondweed (Potamogeton americanus) ranks eleventh among Illinois River valley plants as a source of duck food. It ranks above sago pondweed apparently because it produces more seed.

value, but below the nutgrass group. Seed production studies (Low \& Bellrose ms.) revealed that in 1941 teal grass produced about half as much seed as Cyperus erythrorhizos and almost as much as did duck potato per area unit.

Duck potato, Sagittaria latifolia, fig. 9 , has an index value, table 3 , about twofifths as great as that of giant bur-reed. Incidentally, in 1941, bur-reed produced about two-fifths more seed per unit of area than did duck potato. For the most part, the large tubers of duck potato, often a foot or more underground, are not available as duck food. However, at times canvasbacks and ringnecks have succeeded in obtaining numerous tubers, which considerably raised the value of duck potato for certain areas.

Marsh smartweed, Polygonum Muhlenbergii, fig. 10, has in table 3 an index value of 0.84 , which places it slightly below duck potato. Beds of this species will not produce seed when growing out of water; optimum production occurs in water 12 to 18 inches deep. In several areas, beds produced no seed be- cause of a lack of water. This species would rank somewhat higher if all the beds that failed to produce seed were excluded from the calculations.

Longleaf pondweed, Potamogeton americanus, fig. 11, ranks below marsh smartweed in index value, table 3 , despite the fact it outproduces the latter in seed yield by a wide margin. This may indicate that, because of the greater depth of water at which the plants grow, seeds of aquatic plants are less accessible to dabbling ducks than are those of marsh plants.

Buttonbush, Cephalanthus occidentalis, seldom grows in the areas that were mapped, occurring usually as a part of, or within, the shoreline. Since it is also a woody species, its abundance was not determined for most areas. However, in the Crane Lake region, its abundance was determined in 1939 and 1940 . When there was a dearth of other duck foods in this area, 1939 , the index rating was 0.94 ; when there was an abundance of other foods, 1940 , the index rating dropped to 0.12 . A study of the food consumption on 
other areas substantiates the Crane Lake observations. Seed production of buttonbush is not known to vary greatly from year to year; therefore, we must conclude that ducks do not relish the seeds and that these seeds are sufficiently palatable to be taken extensively only when other foods are lacking.

Spike rushes, Eleocharis spp., include mainly the Eleocharis palustris group. These short, round-stemmed species, growing on moist soil or in shallow water may be excellent duck foods in some years and poor foods in others, as illustrated by the index values in tables 4,5 and 6 . Tables 5 and 6 show that, in 1939 and 1940, spike rushes formed about the same per cent of vegetation at the lakes studied. Yet in the first year the seed of these species consumed by ducks was three times as great as in the

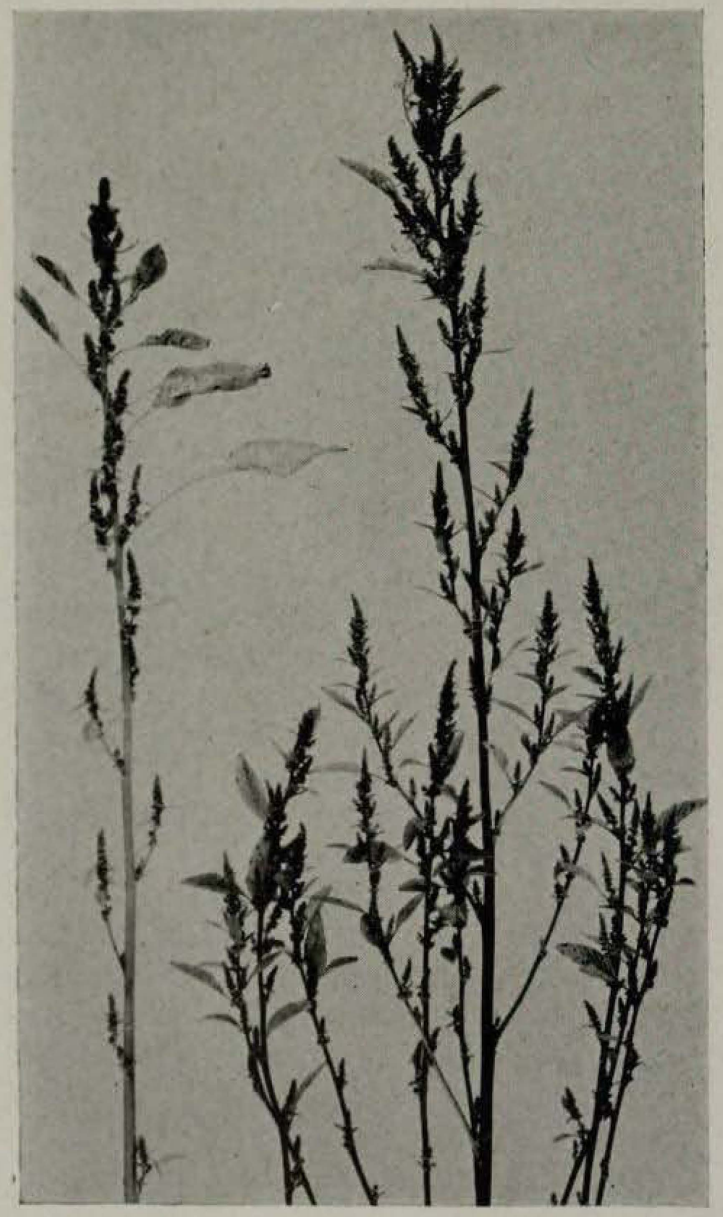

Fig. 12.-Water hemp (Acnida tuberculata) better known as pigweed, is generally a large, coarse moist-soil plant. It is of lower value as a source of duck food than are most other species growing on the Illinois River mud flats. second year. We are at a loss to account for this variance. The 3-year index rating for these species places their duck food value slightly below that of the longleaf pondweed, table 3 .

Water hemp, Acnida tuberculata, fig. 12 , a large, coarse herb growing on drier soil sites than other moist-soil plants, has small seeds, pin-headed in shape, that may not always be as available as seeds of the other species of this group. Its index value for $1938-40$ is 0.34 , table 3 . The data include seeds produced prior to 1938 , a year in which only a very few plants of this species grew in the areas studied. The 1940 rating of 0.30 is probably the best indicator of its true value, table 6 . Such moist-soil plants as smartweeds, millets and rice cut-grass are apparently about 10 to 40 times as good sources of duck food as is water hemp.

Marsh cord grass, Spartina Michauxiana, may be a fair duck food, as shown in table 3 , with an index value of 0.24 . This figure places it in a better position as a duck food in the Illinois River valley than it is customarily accorded elsewhere.

Sago pondweed, Potamogeton pectinatus, fig. 13, is generally regarded as one of the most excellent duck foods on the North American continent. However, it falls far short of this ideal in the Illinois River valley. Tables 4, 5 and 6 show that its 1938 index rating was 0.10 , its 1939 rating was 0.06 and its 1940 rating was 0.24 . Table 3 shows a 3 -year index value of 0.10 . The low status of this highly rated species in the Illinois River region is due to its low seed yield here. Very little foliage and few tubers of this species were found in the 3,200 gizzards analyzed.

The apparently low seed yield of sago pondweed was substantiated by studies made in 1941 by Low \& Bellrose (ms.), which revealed that this plant produced less seed per area unit than 23 other aquatic and moist-soil plants in the Illinois River valley.

White waterlily, Castalia tuberosa, has an index figure of 0.10 for the 3 -year period, table 3 . However, its value may vary from year to year and place to place, depending on its own seed yield and on the presence or absence of other 


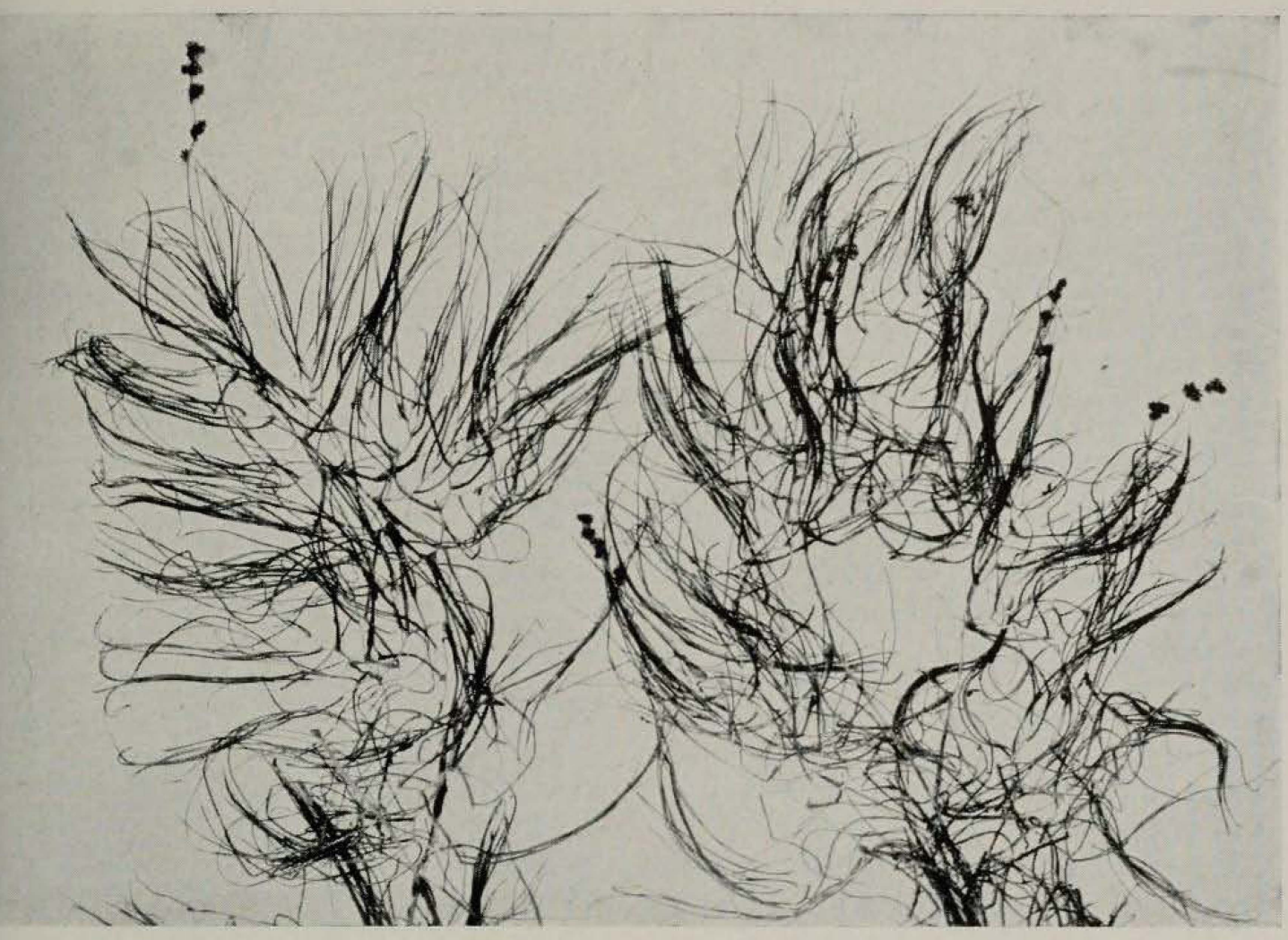

Fig. 13. - Sago pondweed (Potamogeton pectinatus) has the reputation of being one of the best waterfowl food plants in North America. However, in the Illinois River valley it ranks sixteenth among 25 species or groups. Its low rating in Illinois appears attributable to its low seed yield in this area and to the fact that its foliage is seldom found in duck gizzards here.

food resources. A serious paucity of ther duck food plants in 1938 may have accounted for its unusually high rating of 0.26 in that year, table 4 ; when other food resources were greater, 1939 , its index rating was less than 0.02 , table 5 . At Crane Lake in 1938, white waterlily rated 0.19 , but it dropped to 0.01 in value the following year. This was doubtlessly due to the inhibition of fruiting caused by low water. The above data rank this species as poor to fair in food value, somewhat higher than the American lotus.

Pickerelweed, Pontederia cordata, fig. 14 , is not given a numerical value in table 3. It was impossible to secure an index figure for this plant covering the 3 -year study period because of the infinitesimal amounts of seed consumed by ducks. An index value of 0.03 , derived from data obtained in 1939 at Crane Lake, places pickerelweed for that year and area above river bulrush and American lotus. If its low value is adequately portrayed by this small

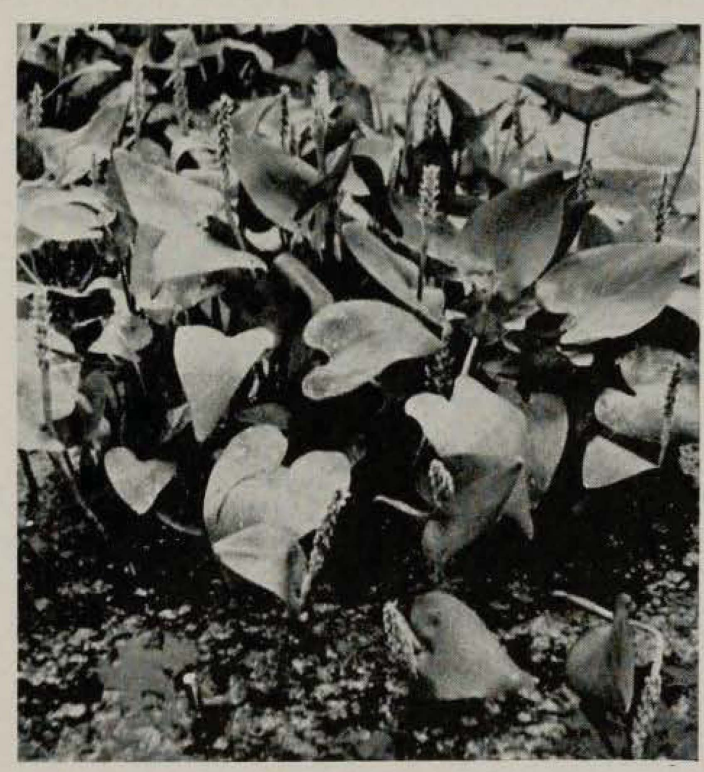

Fig. 14.-Fickerelweed (Pontederia cordata) is of doubtful value as a duck food plant in spite of the fact that it is one of the top-ranking seed producers in the Illinois River region. Its blue flowers and heart-shaped leaves distinguish it from duck potato, which has white blossoms and arrowhead-shaped leaves. 
sample, then the low use must be due to low palatability rather than lack of availability, for this species is one of the top-ranking seed producers, as shown by a 1941 study (Low \& Bellrose ms.).

River bulrush, Scirpus fluviatilis, a coarse, dominant marsh plant, frequently forms dense beds of 50 to 700 acres in the Illinois River valley. Only rarely in this area does it fruit, and then only in small patches; seeds are seldom available for food. This circumstance accounts for the fact that although river bulrush formed over 26 per cent of the vegetation for the 3-year study period, its seed accounted for only 0.50 per cent of the uncultivated plant parts consumed by waterfowl; its index value for the 3-year period is 0.02 , table 3 . At Lake Chautauqua, in 1938, when river bulrush beds produced more than the usual amount of seed, the index value of this plant for the area was 0.23 .

Since river bulrush covers extensive areas that might well be occupied by more valuable food producers, it must be regarded as one of the most pernicious weeds in many waterfowl habitats of the Illinois River valley.

American lotus, Nelumbo lutea, fig. 15 , is next to river bulrush in abundance in lakes adjacent to the Illinois River. Unlike this bulrush, however, lotus produces a fair amount of seed. Yet its index rating is 0.02 , table 3 , the same as river bulrush. Its slight value as a duck food and its dominance over many other aquatic plants of greater value make this species a weed in the migratory waterfowl habitats of the Illinois River valley.

Its low value as a duck food plant during October and November must be attributed to the unpalatability of the hard, nutlike seeds. Field observations indicate that before the seeds fully ripen, in late August and early September, wood ducks feed extensively on them. At that time the pericarp and cotyledons of the seed are soft.

Marsh mallow, Hibiscus militaris, is not generally regarded as a waterfowl food plant. However, in the 3-year investigation period it averaged 0.01 per cent of the vegetation of the marshes studied, table 3 , and a few seeds were consumed by ducks.
Southern naiad, Najas guadalupensis, is apparently a poor duck food in the Illinois River valley. While it formed 0.12 per cent of the vegetation on the areas studied, table 3 , only a smattering of seeds was found in the gizzards analyzed. Martin \& Uhler (1939), in commenting on the value of the northern and southern naiads in the country as a whole, term them excellent duck foods.

Wild rice, Zizania aquatica, fig. 16 , is often regarded as the food supreme for waterfowl. This may well be the case in regions where its abundance is measured in thousands of acres. However, despite the fact that it formed beds of 3 to 81 acres in several Illinois River valley lakes, none of its seeds were found in any of the duck stomachs analyzed, table 3. A possible explanation for the absence of seeds may be that few were available, for in August and September thousands of red-winged blackbirds were observed feeding on the ripening seed. Seeds that escape the blackbirds may be inaccessible among the vegetation debris and muck of the lake bot-

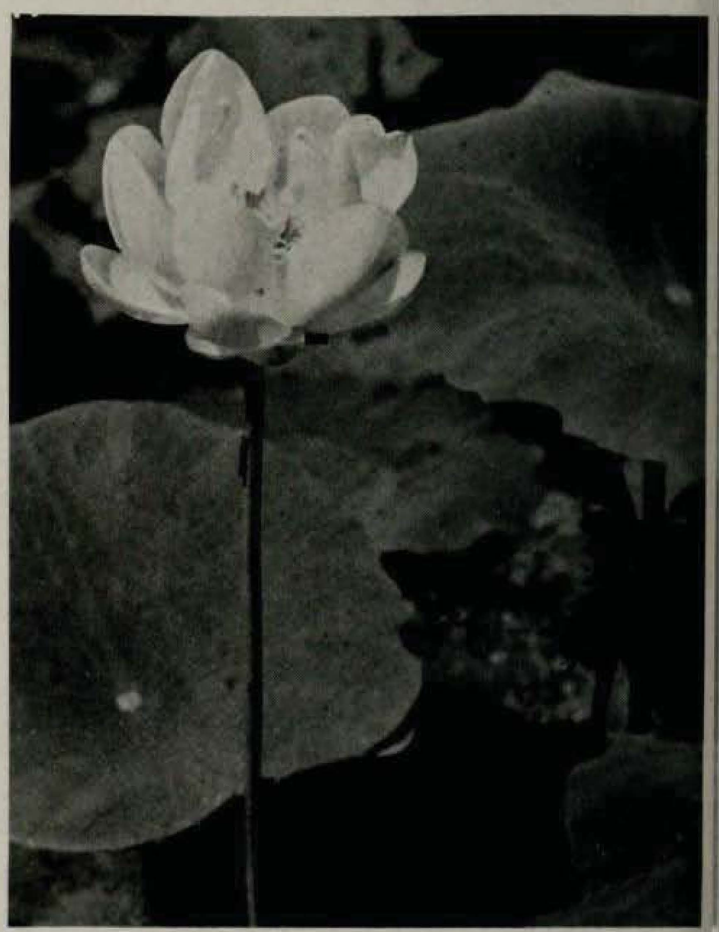

Fig. 15.-American lotus (Nelumbo lutea), or yorkey nut as it is often called locally, is seldom utilized by ducks despite its abundance. Its low value as a food plant is due probably to the unpalatability of its hard, nutlike seeds. 
toms; most of the seeds fall a month before the greatest numbers of ducks arrive. McAtee $(1939$, p. 33$)$ in commenting on the value of wild rice states: "This plant has a great reputation as a producer of food for wildfowl - too high a rating, perhaps, considering its local and seasonal availability."

Small pondweed, Potamogeton pusillus, is another species that is generally

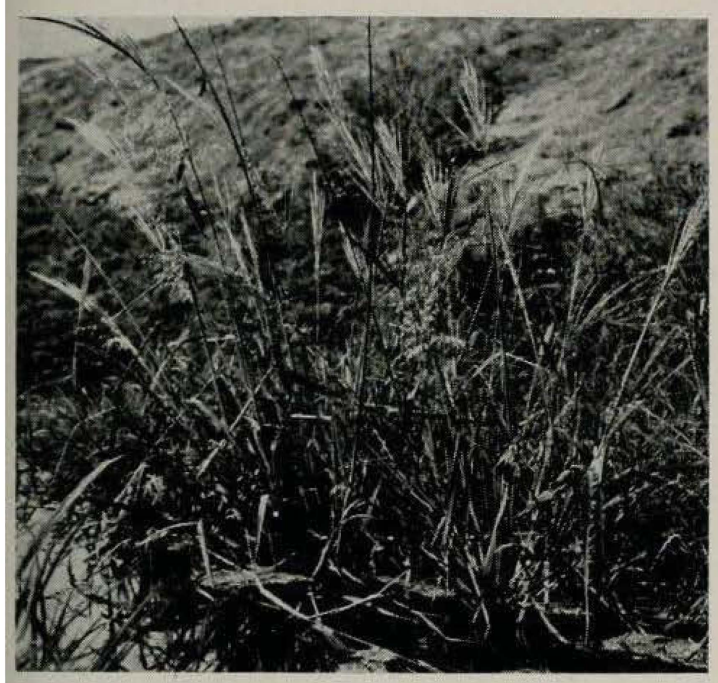

Fig. 16. - Wild rice (Zizania aquatica) is not a valuable duck food plant in the Illinois River valley; few of the seeds are available during the season of the principal waterfowl flight in the fall months.

considered a good waterfowl food plant. Although it amounted to 0.05 per cent of the vegetation, table 3 , no foliage or seeds were found in any of the stomachs analyzed. Studies of seed yield in 1941 (Low \& Bellrose ms.) revealed that it was one of the lowest producers. We have noted that the vegetative parts, after fruiting time in late July and early August, generally disintegrate. Whether disintegration is caused by green algae, by the competition of coontail and southern naiad, or by some unknown factor, we do not know.

Longleaf ammannia, Ammannia coccinea, is a moist-soil plant that has occurred fairly abundantly at Clear Lake. No evidence was obtained that this species was ever used as food by ducks, table 3 .

Plant parts of a large number of other species were consumed in infinitesimal amounts; likewise some other species were found in the field in amounts too small to tabulate, table 3 .

\section{Discussion}

That the true value to waterfowl of the various aquatic and moist-soil plants cannot be determined solely from the use made of them by the birds is evident after consideration of a few outstanding instances. Based solely on use, Walter's millet ranks sixth in value among duck food plants of the Illinois River valley, slightly below marsh smartweed, table 3 . When abundance as well as use is considered, Walter's millet is second in rank, nearly 13 times as great in value as marsh smartweed, which places ninth in value, table 3 . In another instance, based on use only, coontail ranks second, three-fifths as valuable as the leading rice cut-grass; however, after the abundance figure is considered, coontail drops to seventh place, with about one-seventh the value of rice cutgrass. Giant bur-reed, according to use made by ducks, ranks sixteenth in value. When the meager occurrence of the burreed is taken into consideration, it jumps to sixth in value.

Although many extraneous and diverse factors have prevented us from obtaining exact values for duck food plants, we believe that, by considering both the abundance and use of such plants, it is possible to ascertain more nearly the true value of plant species, as food for waterfowl, than by using data based solely on the quantity of the items taken.

What determines the duck food value of various aquatic plants? Logically, availability and palatability are two most important factors. We believe evidence discussed in this paper shows that availability, as measured by food yield and accessibility, determines the value of most plants generally considered as sources of duck food. It should be noted that, in many species, seed yield and value go hand in hand. In other species, depth of water evidently affects availability, through making the food source less, or more, easily accessible to ducks, especially dabbling ducks. We may tentatively assume that seeds of moist-soil plants are more 
easily accessible than those of emergent aquatic species, which, in turn, are more easily accessible than floating or submerged aquatic plants.

That palatability plays an important role in determining the food value of several species is also quite evident. Both the pickerelweed and buttonbush are heavy seed producers, the food is fairly accessible, and yet the index value is low. American lotus is a medium food producer, the seeds are fairly accessible, and yet the index value is very low. Palatability in these species must be the operative factor in determining their meager use by ducks.

\section{Summary}

Employing data based upon the occurrence of the plants, as well as upon consumption by ducks of the plant parts, the writers have attempted to present an accurate appraisal of the value of certain plants of the Illinois River valley as waterfowl food sources.

$\mathrm{By}$ dividing the per cent of use made by ducks by the per cent of abundance of the important aquatic and moist-soil plants occurring in the valley, it was possible to secure an index figure of value for each of these species. We believe the figures obtained to be far more reliable indicators of value as waterfowl food sources than are data derived only from plant parts taken by the birds.

Numerous factors, such as seed production and accessibility, influence sources of supply that vary with the habitat and year. Taking cognizance of these variables (as discussed under each species) makes it seem advisable to judge the value of each species on the figures for no one year, but to use the index value for the year or years that seem most typical. This procedure places 25 plants or groups in the following descending order of value as food for ducks in the Illinois River valley, 1938, 1939 and 1940. Tables 3, 4, 5 and 6 give comparative values for species and years.

\section{Excellent Duck Food Sources}

1. Rice cut-grass, Leersia oryzoides (Linnaeus) Swartz
2. Walter's millet, Echinochloa Walteri (Pursh) Nash

3. Wild and Japanese millets, Echinochloa crusgalli (Linnaeus) Beauvois and $E$. frumentacea (Roxburgh) Link, respectively

4. Moist-soil smartweeds

a. Largeseed smartweed, Polygonum pennsylvanicum Linnaeus

b. Nodding smartweed, Polygonum lapathifolium Linnaeus

c. Swamp smartweed, Polygonum hydropiperoides Michaux

d. Miscellaneous, Polygonum spp.

5. Nutgrasses

a. Chufa, Cyperus esculentus Linnaeus

b. Red-rooted cyperus, Cyperus erythrorhizos Muhlenberg

c. Straw-colored cyperus, Cyperus strigosus Linnaeus

\section{Good Duck Food Sources}

6. Giant bur-reed, Sparganium eurycarpum Engelmann

7. Coontail, Ceratophyllum demersum Linnaeus

8. Teal grass, Eragrostis hypnoides (Lamarck) Britton, Sterns \& Poggenberg

9. Duck potato, Sagittaria latifolia Willdenow

10. Marsh smartweed, Polygonum Muhlenbergii (Meisner) Watson

11. Longleaf pondweed, Potamogeton americanus Chamisso \& Schlechtendal

\section{Fair Duck Food Sources}

12. Buttonbush, Cephalanthus occidentalis Linnaeus

13. Spike rushes, principally Eleocharis palustris (Linnaeus) Roemer \& Schultes

14. Water hemp, Acnida tuberculata Moquin-Tandon

15. Marsh cord grass, Spartina Michauxiana Hitchcock

16. Sago pondweed, Potamogeton pectinatus Linnaeus

17. White waterlily, Castalia tuberosa (Paine) Greene 
Poor Duck Food Sources

18. River bulrush, Scirpus fluviatilis (Torrey) Gray

19. American lotus, Nelumbo lutea (Willdenow) Persoon

20. Pickerelweed, Pontederia cordata Linnaeus

21. Marsh mallow, Hibiscus militaris Cavanilles

22. Southern naiad, Najas guadalupensis (Sprengel) Morong
23. Wild rice, Zizania aquatica Linnaeus

24. Small pondweed, Potamogeton pusillus Linnaeus

25. Long-leaved ammannia, Ammannia coccinea Rottboell

It should be noted that the five leading plants, or groups, are moist-soil species. The moist-soil plants as a group are better seed-yielders than the truly aquatic plants and their seeds are more readily available to most ducks.

\section{I T E R A T UR E C I T E D}

Bellrose, Frank C., Jr.

1941. Duck food plants of the Illinois River valley. Ill. Nat. Hist. Surv. Bul. $21(8): 237-80$. Frontis. +35 figs.

Bellrose, Frank C., and Harry G. Anderson

1940. Preliminary report on availability and use of waterfowl food plants in the Illinois River valley. Ill. Nat. Hist. Surv. Biol. Notes 15. 14 pp. (Mimeographed.)

\section{Cottam, Clarence}

1939. Food habits of North American diving ducks. U. S. Dept. Ag. Tech. Bul. 643. 139 pp., illus.
Martin, A. C., and F. M. Uhler

1939. Food of game ducks in the United States and Canada. U. S. Dept. Ag. Tech. Bul. 634. 156 pp., illus.

McAtee, W. L.

1918. Food habits of the mallard ducks in the United States. U. S. Dept. Ag. Bul. 720. 35 pp., illus.

1939. Wildfowl food plants. Collegiate Press, Inc., Ames, Iowa. 141 pp., illus.

\section{Pirnie, Miles D.}

1935. Michigan waterfowl management. Mich. Dept. Cons., Lansing. 328 pp., illus. 


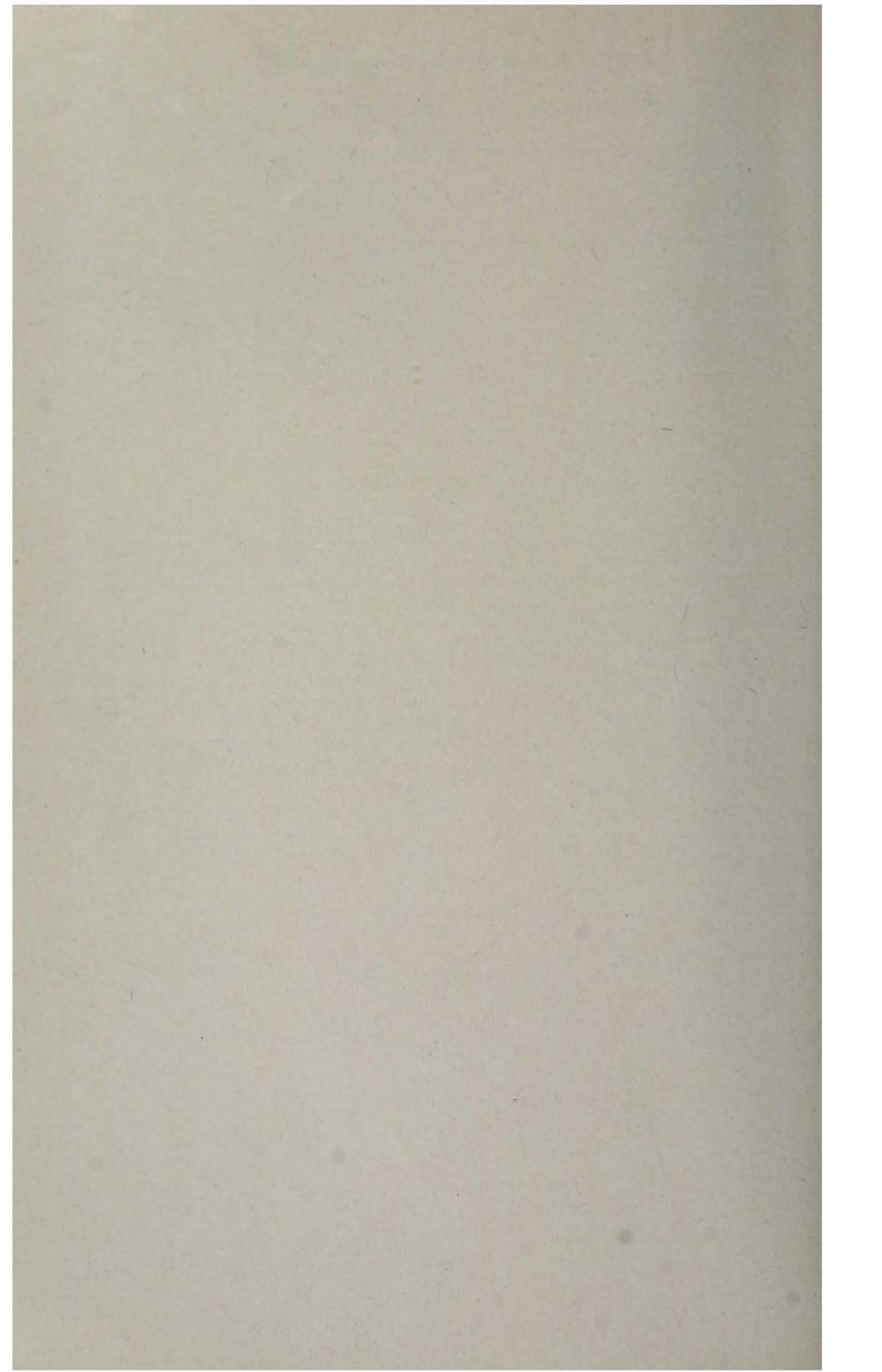

